In Cooperation with Environment Canada's National Water Research Institute and the Great Lakes Protection Fund

\title{
Base Flow in the Great Lakes Basin
}

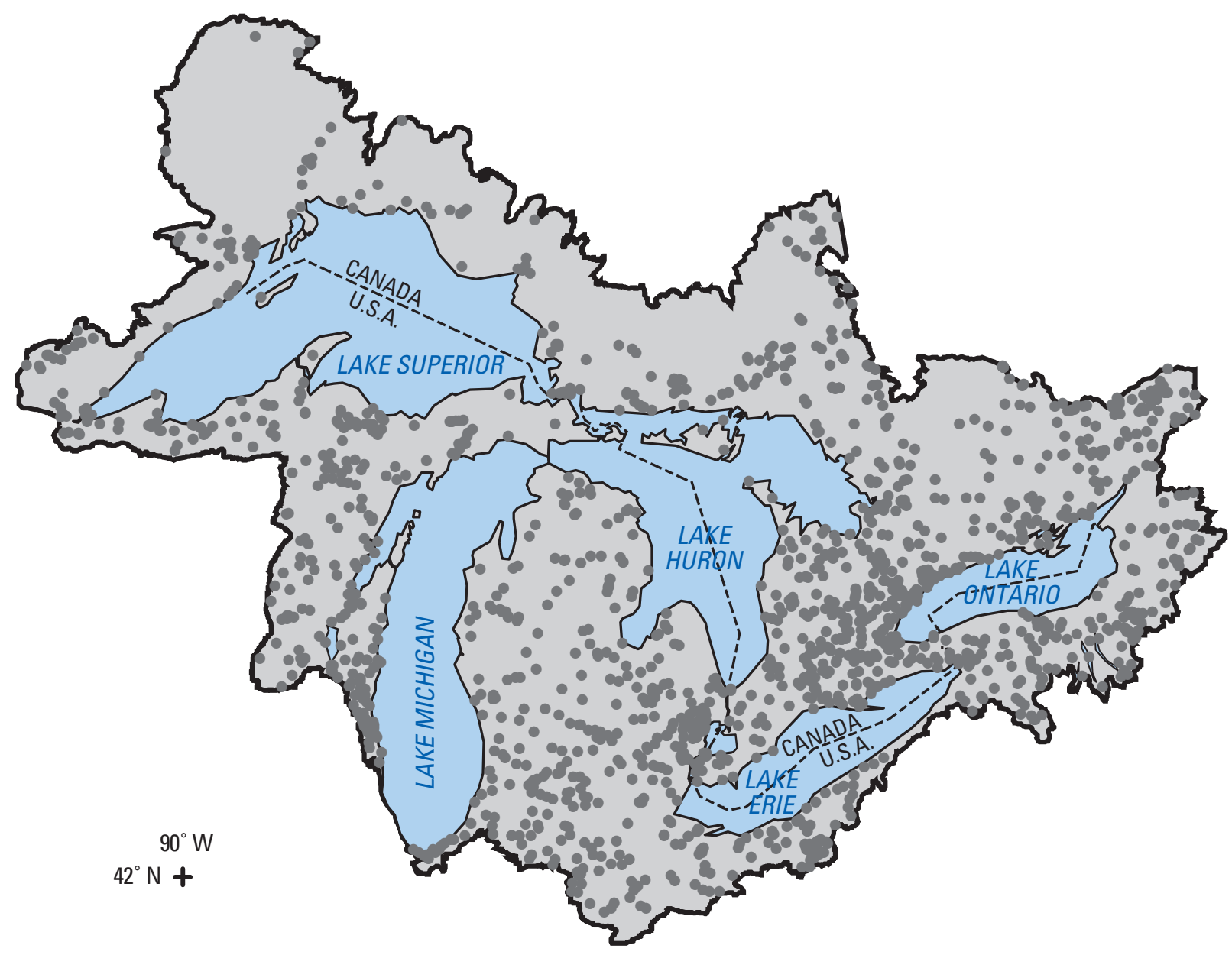

Scientific Investigations Report 2005-5217 
Cover Figure. Study area with the location of the gages used in the study shown. 


\section{Base Flow in the Great Lakes Basin}

By B.P. Neff, S.M. Day, A.R. Piggott, and L.M. Fuller

Prepared in Cooperation with Environment Canada's National Water Research Institute and the Great Lakes Protection Fund

Scientific Investigations Report 2005-5217 


\section{U.S. Department of the Interior \\ Gale A. Norton, Secretary \\ U.S. Geological Survey \\ P. Patrick Leahy, Acting Director}

U.S. Geological Survey, Reston, Virginia: 2005

For sale by U.S. Geological Survey, Information Services
Box 25286, Denver Federal Center
Denver, CO 80225
For more information about the USGS and its products:
Telephone: 1-888-ASK-USGS
World Wide Web: http://www.usgs.gov/

\footnotetext{
Any use of trade, product, or firm names in this publication is for descriptive purposes only and does not imply endorsement by the U.S. Government.

Although this report is in the public domain, permission must be secured from the individual copyright owners to reproduce any copyrighted materials contained within this report.

Suggested citation:

Neff, B.P., Day, S.M., Piggott, A.R., Fuller, L.,M., 2005, Base Flow in the Great Lakes Basin: U.S. Geological Survey Scientific Investigations Report 2005-5217, 23 p.
} 


\section{CONTENTS}

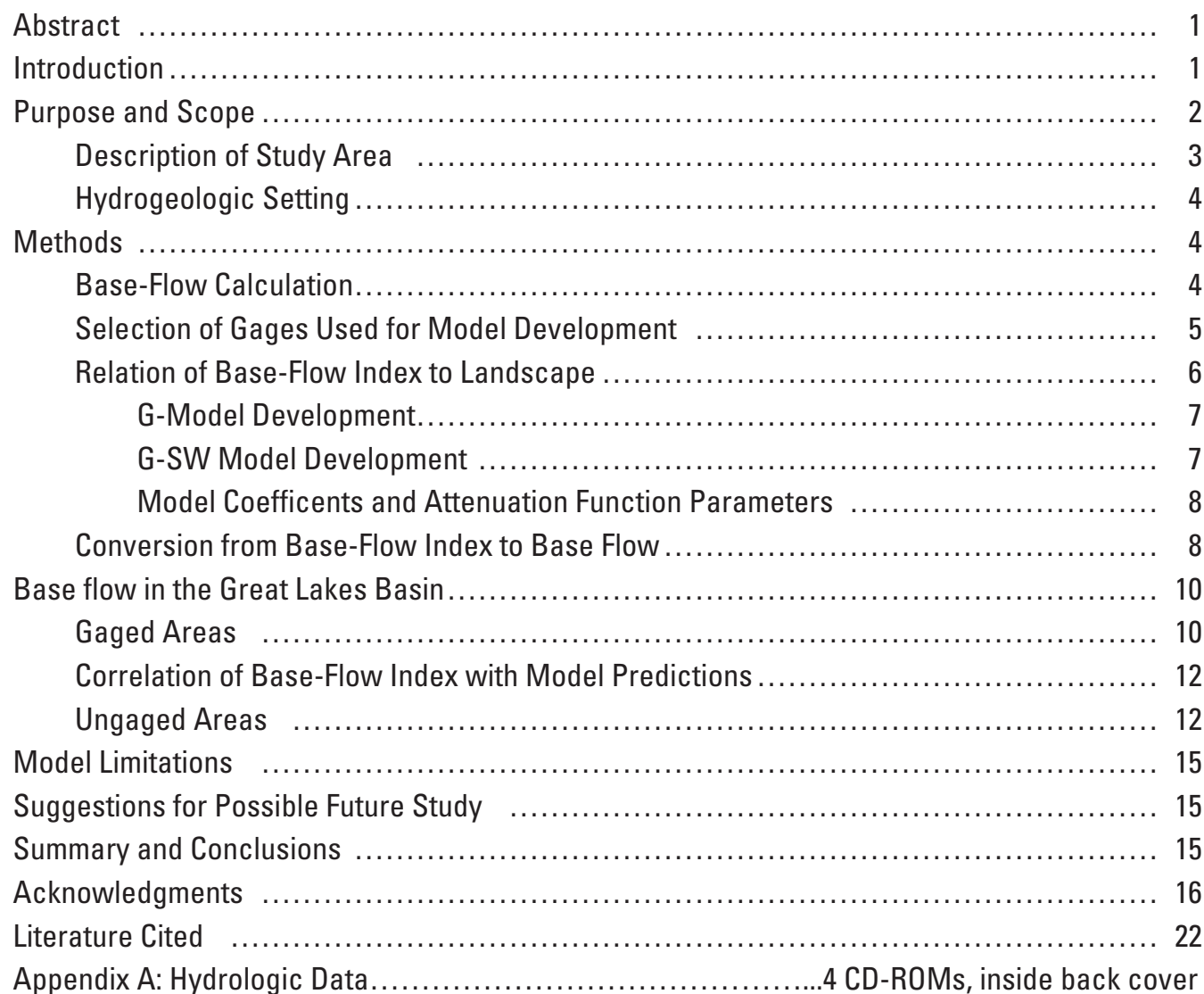

\section{FIGURES}

1. Map showing location of the study area in Ontario, Canada and the eight Great Lake States of Illinois, Indiana, Michigan, Minnesota, New York, Ohio,

Pennsylvnia, and Wisconsin

2. Graph showing hydrograph separation for the streamflow record of Nith River at New Hamburg, Ontario, streamflow-gaging station number 02GA018 using the UKIH method

3. Map showing the Surficial Geology of the study area $\ldots \ldots \ldots \ldots \ldots \ldots \ldots \ldots$

4. Graph showing the comparison of $1971-2000$ average streamflow to length of record average streamflow at 555 streamflow gages in Ontario and 1936 streamflow gages in the eight Great Lakes States of Illinois, Indiana, Michigan, Minnesota, New York, Ohio, Pennsylvania, and Wisconsin

5. Map showing the results of base-flow separation using PART for streamflow records at streamflow-gaging stations within the study area

6. Graph showing the temporal distribution of daily streamflow data in Ontario, Canada and the eight Great Lakes States of Illinois, Indiana, Michigan, Minnesota, New York, Ohio, Pennsylvania, and Wisconsin, 1860-2001 
7. Maps showing base-flow indexes for 8-digit Hydrologic Unit Codes in the U.S. and the tertiary watersheds in Canada based on the A) G Model and B) G-SW Model calibrated using PART hydrograph analysis results.

\section{TABLES}

1. Comparison of long-term trends in base flow and corresponding trends in base-flow index for streamflow records at selected streamflow-gaging stations in the Great Lakes Basin

2. Base-flow index statistics for streamflow records of streamflow-gaging stations in the Great Lakes Basin based on six hydrograph-separation methods

3. Percentage of model predictions for gaged watersheds in the study area within 0.1 and 0.2 of base-flow index (BFI) values determined from hydrograph-separation analyses

4. Long-term average base-flow index estimates for each Hydrologic Unit Code (HUC) and tertiary watershed in the Great Lakes Basin

5. Regression model statistics determined in previous studies used in relating base-flow index to watershed variables in the Great Lakes Basin.

\section{Conversion Factors}

Inch/Pound to SI

\begin{tabular}{lcl}
\hline Multiply & By & To obtain \\
\hline \multicolumn{3}{l}{ Length } \\
\hline foot (ft) & 25.4 & millimeter $(\mathrm{mm})$ \\
mile (mi) & 0.3048 & meter $(\mathrm{m})$ \\
\hline \multicolumn{3}{c}{ Area } \\
\hline square mile $\left(\mathrm{mi}^{2}\right)$ & 2.609 & kilometer $(\mathrm{km})$ \\
square foot $\left(\mathrm{ft}^{2}\right)$ & 0.0929 & square meter $\left(\mathrm{m}^{2}\right)$ \\
\hline & Volume \\
\hline cubic foot $\left(\mathrm{ft}^{3}\right)$ & 0.02832 & cubic meter $\left(\mathrm{m}^{3}\right)$ \\
\hline \multicolumn{3}{c}{ Flow rate } \\
\hline cubic foot per second $\left(\mathrm{ft}^{3} / \mathrm{s}\right)$ & 0.02832 & cubic meter per second $\left(\mathrm{m}^{3} / \mathrm{s}\right)$ \\
\hline \multicolumn{3}{c}{ Hydraulic conductivity } \\
\hline foot per day (ft/d) 0.3048 & meter per day $(\mathrm{m} / \mathrm{d})$ \\
\hline
\end{tabular}

Temperature in degrees Celsius $\left({ }^{\circ} \mathrm{C}\right)$ may be converted to degrees Fahrenheit $\left({ }^{\circ} \mathrm{F}\right)$ as follows: ${ }^{\circ} \mathrm{F}=\left(1.8 x^{\circ} \mathrm{C}\right)+32$

Temperature in degrees Fahrenheit $\left({ }^{\circ} \mathrm{F}\right)$ may be converted to degrees Celsius $\left({ }^{\circ} \mathrm{C}\right)$ as follows:

${ }^{\circ} \mathrm{C}=\left({ }^{\circ} \mathrm{F}-32\right) / 1.8$ 


\title{
Base Flow in the Great Lakes Basin
}

\author{
By B.P. Neff, S.M. Day, A.R. Piggott, and L.M. Fuller
}

\section{Abstract}

Hydrograph separations were performed using the PART, HYSEP 1, 2, and 3, BFLOW and UKIH methods on 104,293 years of daily streamflow records from 3,936 streamflow-gaging stations in Ontario, Canada and the eight Great Lakes States of Illinois, Indiana, Michigan, Minnesota, New York, Ohio, Pennsylvania, and Wisconsin to estimate base-flow index (BFI) and base flow. BFI ranged an average of $0.24 \mathrm{BFI}$ depending on which hydrograph-separation method was used. BFI data from 959 selected streamflow-gaging stations with a combined 28,784 years of daily streamflow data were used to relate BFI to surficial geology and the proportion of surface water within the gaged watersheds. This relation was then used to derive estimates of BFI throughout the Great Lakes, Ottawa River, and upper St. Lawrence River Basins at a scale of 8-digit hydrologic unit code (HUC) watersheds for the U.S. and tertiary watersheds in Canada. This process was repeated for each of the six hydrograph-separation methods used. When applied to gaged watersheds, model results predicted observed base flow within 0.2 BFI up to 94 percent of the time. Estimates of long-term (length of streamflow record) average annual streamflow in each HUC and tertiary watershed were calculated and used to determine average annual base flow from BFI estimates. Possibilities for future study based on results from this study include long-term trend analysis of base flow and improving the scale at which base-flow estimates can be made.

\section{Introduction}

Estimating (or determining) base flow in the Great Lakes Basin (fig. 1) is important to proper management of these important water bodies. Base flow provides a relatively stable supply of high quality water with high clarity and stable temperature. This streamflow is important to stream biota and helps support recreation based industries such as recreational fishing and kayaking. In 1998, the Great Lakes Protection Fund and U.S. Geological Survey (USGS) cooperatively produced a preliminary assessment of base flow in the Great Lakes Basin (Holtschlag and Nicholas, 1998). The preliminary assessment was successful at meeting the goal of raising awareness of the effect of ground water in the Great Lakes water balance. Subsequently, many conferences, workshops, scientific literature, and legislation specifically included information on base flow.

Water-management decisions require both awareness and state-of-the-art knowledge. Holtschlag and Nicholas (1998) used a limited dataset (data for the U.S. only) to estimate the ground-water component of streamflow in gaged watersheds and a crude extrapolation to estimate the ground-water component of streamflow in ungaged watersheds, including all of the Canadian portion of the Great Lakes Basin. Consequently, the estimates of base flow to some of the Great Lakes are believed to be considerably inaccurate. Therefore, the USGS, in cooperation with Environment Canada's National Water Research Institute and the Great Lakes Protection Fund, began a study in June 2002 to more accurately assess base flow in the Great Lakes Basin.

The primary objective of this study is to produce estimates of base flow in watersheds tributary to the Great Lakes. Coordinated binational estimates of base flow generated in this study are useful at many levels. The principal beneficiaries are expected to be those making water-management decisions in the Great Lakes. Additionally, the scientific and research community should benefit from a dataset that is applicable to many water-resources issues, including the development of 


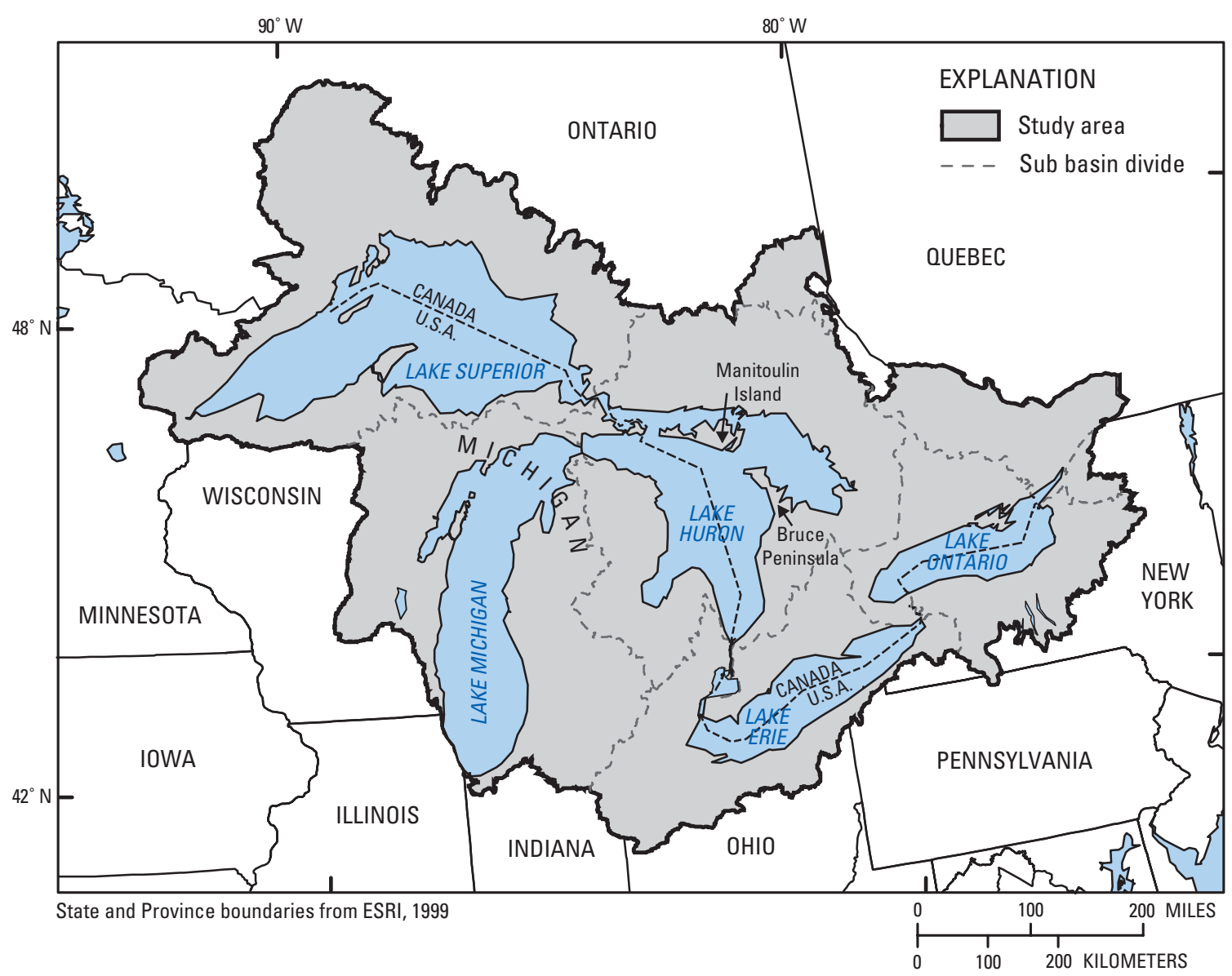

Figure 1. Location of the study area in Ontario, Canada and the eight Great Lake States of Illinois, Indiana, Michigan, Minnesota, New York, Ohio, Pennsylvania, and Wisconsin.

non-point source-water protection strategies. In this report, base flow in the Great Lakes Basin (alternately termed indirect ground-water discharge to the Great Lakes by some authors) is defined here as the discharge of ground water to streams tributary to the Great Lakes. The term "basin" is used to describe the Great Lakes watershed, and the term "watershed" is used to describe the watersheds of streams tributary to the Great Lakes. The term "gage" is hereafter used to describe a streamflow-gaging station unless otherwise stated. The term "gaged area" is used to describe the area tributary to a given gage or gages. The term "ungaged area" is used to describe areas that are not tributary to any gages used in this study. In general, ungaged areas in this study are watersheds represented by 8 -digit hydrologic unit codes (HUCs) for the U.S. and tertiary watersheds for Canada, which may contain gaged areas. This approach was taken to take advantage of the availability of geographic datasets for these watersheds.

\section{Purpose and Scope}

The purpose of this report is to present estimates of base flow in streams tributary to the Great Lakes from gaged and ungaged areas in the U.S. and Canada. In gaged areas, these estimates are based on hydrograph separation of daily streamflow records (fig. 2). In ungaged areas, these estimates are based on regression models calibrated to the hydrograph-separation results. Many methods of hydrograph separation are available and base-flow estimates are variable depending on which of these methods are used. To capture this variability and to maximize the transferability of study results, estimates are provided using six methods of hydrograph separation. None of these hydrograph-separation methods, or sets of results, is considered better or worse than the other methods.

Hydrograph separations were performed on length of record daily stream discharge data from 3,936 gages 


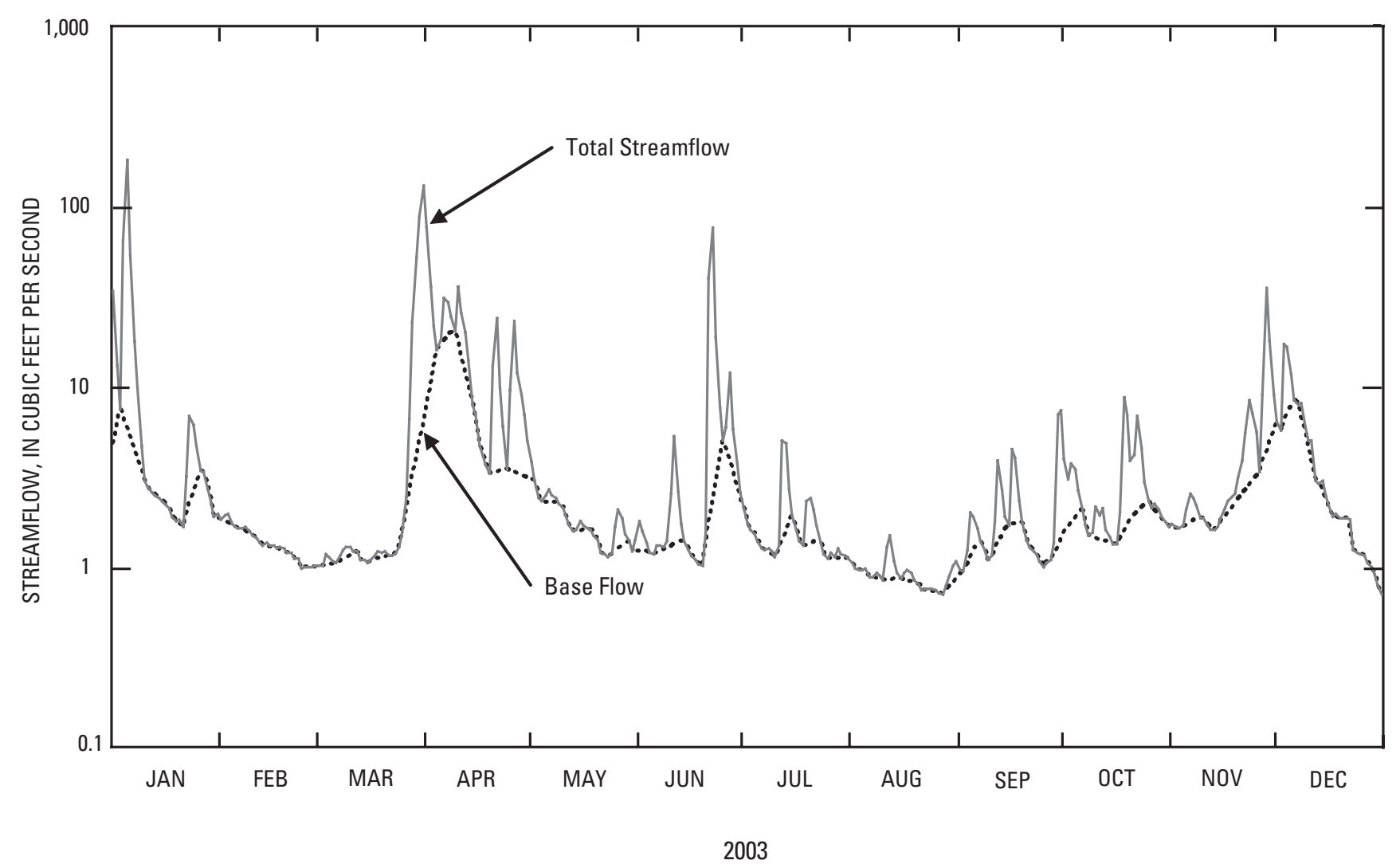

Figure 2. Hydrograph separation for the streamflow record of Nith River at New Hamburg, Ontario, streamflow-gaging station number 02GA018 using the UKIH method.

located in Ontario, Canada and the eight Great Lakes States of Illinois, Indiana, Michigan, Minnesota, New York, Ohio, Pennsylvania, and Wisconsin (hereafter referred to collectively as the eight Great Lakes States). Streamflow records analyzed total approximately $37,000,000$ daily observations of streamflow, or 102,000 years of daily streamflow records. Two models were developed to describe base flow in ungaged areas and were calibrated using hydrograph-separation results from 959 of these gages. The period of record for these 959 gages totaled approximately 102,000 years, and averaged 29.9 years at each gage. The range in length of record used to calibrate the models was from 3.0 years to 103.8 years. Hydrograph separations were performed using six methods, and the models developed to estimate base flow in ungaged areas were calibrated to the hydrographseparation results from each of the six methods. Therefore, each model was calibrated six times and six sets of base-flow data are presented for each model.
The study area includes the Great Lakes Basin, the Ottawa River Basin, and upper St. Lawrence River Basins, including parts of Ontario, Canada, and Illinois, Indiana, Michigan, Minnesota, New York, Ohio, Pennsylvania, and Wisconsin (fig. 1). The study area was delineated based on gaged and ungaged areas by tracing the National Hydrography Dataset (NHD) channel network upstream from a gage location, then using a flow-corrected digital elevation model (DEM) to identify areas contributing overland flow to the selected stream channels. An implicit assumption to using this approach is that the dimensions of the surface-water watershed are coincident with the dimensions of the shallow groundwater watershed.

\section{Description of Study Area}

Total land area of the study area is approximately $204,000 \mathrm{mi}^{2}$. Fifty-nine percent of the basin is in the 
U.S. and 41 percent is in Canada. The climate of the Great Lakes Basin varies widely from one season to another, and from north to south. Average daily air temperature in January ranges from approximately 28 ${ }^{\circ} \mathrm{F}$ in Indiana and Ohio to $-4{ }^{\circ} \mathrm{F}$ in the northern reaches of the basin north of Lake Superior. Average daily air temperature for July ranges from over $77^{\circ} \mathrm{F}$ in southern Michigan, Ohio, Indiana, and Illinois to less than $63^{\circ} \mathrm{F}$ in the areas north and east of Lake Superior (Government of Canada and U.S. Environmental Protection Agency, 1995, p. 8). Air temperatures over the lakes and in nearshore areas are also strongly affected by lakewater temperature.

Precipitation also varies considerably within the study area. Average annual precipitation ranges from less than 27 in. west of Lake Superior to more than 47 in. east of Lake Ontario (Government of Canada and U.S. Environmental Protection Agency, 1995, p. 8). Average annual snowfall is more variable than rainfall because of the average temperature differences from north to south across the basin, and because of the position of each Great Lake. Areas receiving appreciable snowfall generally are located immediately to the south and east of each lake (Eichenlaub, 1979).

Additional background information (including hydrologic and water-quality data) on the Great Lakes is available. Notable sources are Coordinating Committee on Great Lakes Basic Hydraulic and Hydrologic Data (1977), Eichenlaub (1979), Government of Canada and U.S. Environmental Protection Agency (1995), Great Lakes Commission (2003), Great Lakes Regional Assessment Group (2000), and Manninen and Gauthier (1999).

\section{Hydrogeologic Setting}

Surficial and bedrock geology varies widely throughout the study area. Tills cover 45.6 percent of the Great Lakes Basin and covers more of the U.S. portion (55.6 percent) than the Canadian portion (35.6 percent) of the basin. Coarse-textured sediments cover 27.4 percent of the basin, whereas fine sediments cover 7.6 percent of the basin (fig. 3). Organic sediments are minimal in extent and primarily are present in northern Canadian watersheds. Only 1.8 and 0.9 percent of the study area in Canada and the U.S. contain organic sediments, respectively. Bedrock is at the surface in much of the northern Canadian and northwestern U.S. portions of the Great Lakes Basin. Bedrock covers 30.8 and 5.1 percent of the basin, in Canada and the U.S., respectively, and is principally of Precambrian and Paleozoic age. Bedrock geologic units of the Precambrian and Paleozoic Era are likely to have varying capacities to recharge ground water. Additional information on the geology of the Great Lakes Basin is given in Dorr and Eschman
(1970). Surface water is prevalent throughout the basin but it is particularly abundant in northern Ontario. Up to 97.7 percent of some gaged watersheds are covered by surface-water features such as streams, lakes, and wetlands. Lakes and wetlands cover 12.4 and 7.6 percent of the U.S. and Canadian portions of the basin, respectively.

\section{Methods}

Estimation of base flow in the Great Lakes Basin was done in two major components during this study; (1) for streams and portions of streams that are gaged (gaged areas), and (2) for streams and portions of streams that are ungaged (ungaged areas). Both base flow and base-flow index (BFI) were estimated in gaged areas based on hydrograph separation of length of record daily streamflow records for 3,936 gages in Ontario, Canada, and the eight Great Lakes States. BFI is the average rate of base flow divided by the corresponding average rate of total streamflow. BFI is a number between zero and one; increasing values indicate an increasing ratio of base flow to total streamflow. Six hydrograph-separation methods were used to perform these analyses, generating six datasets describing base flow at current and historical gages.

To estimate base flow in ungaged areas, statistical methods were used to develop regressions to relate BFI to surficial geology and surface-water coverage in gaged watersheds. These regressions were then applied to 8-digit HUC watersheds in the U.S. portion of the study area and tertiary watersheds in the Canadian portion of the study area to estimate BFI at the downstream terminus of these watersheds. To convert BFI estimates to base flow (volume/time), total streamflow was first estimated for 8-digit HUC and tertiary watersheds. Then, total streamflow estimates were multiplied by estimates of BFI to calculate total base flow.

Gaged areas were delineated by tracing the NHD channel network upstream from a gage location, then using a flow-corrected DEM to identify the surfacewater watershed of the selected stream channels. It is assumed in this study that the surface-water watershed is coincident with the shallow ground-water watershed. Ungaged areas were delineated as 8-digit HUC (U.S.) and tertiary watersheds (Canada).

\section{Base-Flow Calculation}

For this study, daily streamflow data for all gages in the eight Great Lakes States were extracted from the USGS Automated Data Processing System (ADAPS) database. Similar data for all gages in Ontario were extracted from Version $2000-2.01$ of Environment Canada's Hydrometric Data (HYDAT) CD-ROM (Environ- 


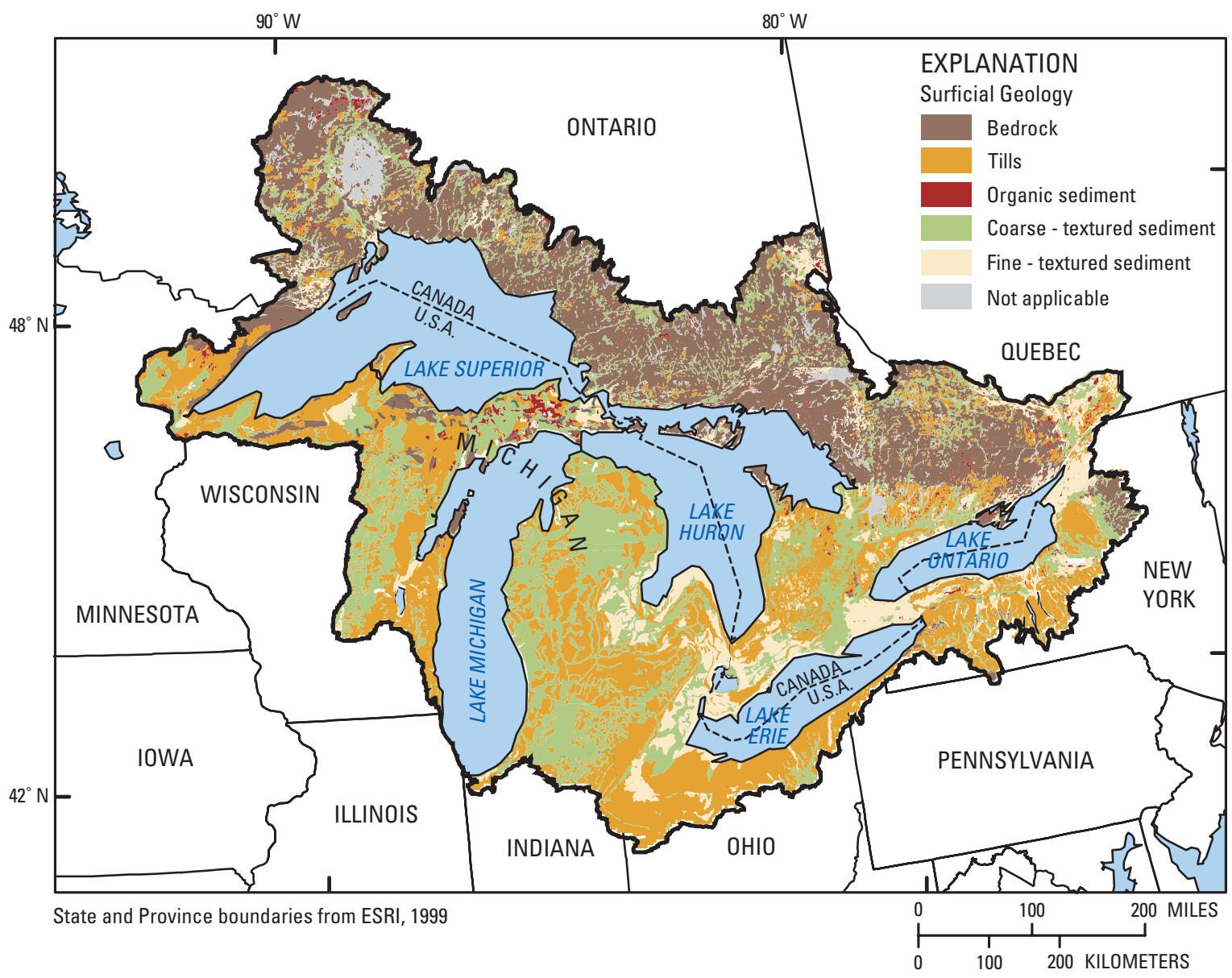

Figure 3. Surficial Geology of the study area.

ment Canada, 2002). In both cases, data were extracted for the length of record at each gage, extending through the most recent data available, September 30, 2001, for U.S. gages and December 31, 2000, for Canadian gages. The data were then processed into a consistent format and partitioned by gage into coherent time series; that is, into one or more blocks of data per gage with no missing values. Temporal referencing of the data was performed using both Julian and Gregorian dates. Supporting information for each gage, such as drainage area and geographic coordinates, were extracted from the NWIS and HYDAT CD-ROM. Calculations were performed using the published units of the data; that is, cubic feet per second for the U.S. and cubic meters per second for Canada. Streamflow records for gages with fewer than 30 consecutive observations of daily average streamflow were disregarded in all analyses. Hydrograph separation was performed on all remaining streamflow data: a total of 779 gages in Ontario and 3,157 gages in the eight Great Lakes States for a total of 3,936 gages.

Six hydrograph-separation methods were applied to daily average streamflow records for the 3,936 gages described above. The hydrograph-separation methods include the fixed-interval, sliding-interval, and local minimum HYSEP methods (Sloto and Crouse 1996), PART (Rutledge 1998), BFLOW (Arnold and Allen, 1999), and UKIH (Piggott and others, 2005) methods. The HYSEP and PART methods were applied only to streamflow data for gages with known drainage areas; the BFLOW and UKIH methods were applied to all of the data. The calculated base-flow data were summarized in terms of average BFI and base flow (volume/time). One value of BFI was calculated for each gage and method of hydrograph separation.

\section{Selection of Gages Used for Model Development}

To develop regression models to describe base flow in ungaged areas, records for some gages were eliminated. Gage selection criteria were: (1) length of record of at least 36 months, (2) location of gage within the study area, (3) availability of a current (2004) geographic information systems (GIS) delineation of the drainage area, and (4) a reasonable quantity of base-flow dis- 
charge per unit drainage area. The length of streamflow record was defined by summarizing streamflow and for months with at least 90 percent of daily values, and then considering the number of months of data summaries. Streamflow records including 36 months (3 years) of data were retained. This threshold was selected to avoid errors in estimating long-term (length of streamflow record) BFI resulting from short-term (seasonal) change in storage within a given watershed. The effect of longterm variability in climate on the streamflow record and hydrograph separations is potentially problematic with a 3-year minimum dataset selection. However, using this parameter permitted the inclusion of many more streamflow records than would have otherwise been the case. It is assumed that such change in storage and climatic variability issues are relatively small in number and are mitigated by considering many hundreds of streamflow records. The second and third criteria listed above applied to all gages to be located inside the study area with appropriate GIS delineations. Specifically, all Canadian gages without a current Water Resources Information Project (WRIP) DEM delineation were eliminated. The final criterion was for gaged watersheds to have a reasonable quantity of streamflow per unit area of watershed, defined as between one-half and two times the average of all ratios of streamflow per unit area watershed. These parameters serve primarily to reveal gross errors in watershed delineation. Tighter restrictions on gage selection would have depleted the spatial variability of gages to an unacceptable number, particularly in northern Ontario. In total, records for 2,766 gages were eliminated. A total of 959 gages were retained for model development, 441 gages in Ontario and 518 gages in the Great Lakes States.

Some potential selection criteria were intentionally not utilized. For example, no selection criterion con- sidered watershed size. Consequently, gages with very large drainage areas $\left(>500 \mathrm{mi}^{2}\right)$ were retained. Also, the quantity of surface water within a watershed was not considered in selection of gages. This action was done, in part, to permit the development of the G-SW model. No special procedure devised to consider the presence of multiple gages on the same stream, which has an unknown effect on model calibration. In not adapting the gage selection criteria to accommodate these special situations, it is assumed that few streamflow records are affected and that by using 959 streamflow records to calibrate the models, the inclusion of a few potentially imperfect streamflow records will have a negligible effect on the results.

Another potential selection criterion for streamflow records that was intentionally not utilized is truncating data to a specific time period. One property of BFI is that it generally remains relatively stable over time (table 1). Some authors have documented trends in total base flow at specific gages in the Great Lakes Basin (Gebert and Krug, 1996), but in these instances the trend in BFI is substantially mitigated as compared to the trend in total base flow (table 1). Because BFI was extrapolated in ungaged areas instead of base flow, it was decided to use the entire length of daily average streamflow record in the analysis.

\section{Relation of Base-Flow Index to Landscape}

In this study, base flow was related to landscape attributes using two models. The first model, the Geology (G) Model, was used to assess the ground-water component of streamflow. The second model, the Geology-Surface Water (G-SW) Model, was used to estimate observed base flow in areas where drainage from wet-

Table 1. Comparison of long-term trends in base flow and corresponding trends in base-flow index for streamflow records at selected streamflow-gaging stations in the Great Lakes Basin (Base-flow index is dimensionless, Base flow is measured in cubic feet per second).

$[\%$, percent.]

\begin{tabular}{|c|c|c|c|c|c|c|c|}
\hline \multirow[b]{2}{*}{ Gaging station } & \multicolumn{2}{|c|}{ Base flow } & \multicolumn{2}{|c|}{ Base-flow index (BFI) } & \multirow[b]{2}{*}{ Agriculture } & \multirow{2}{*}{$\begin{array}{c}\text { Difference in } \\
\text { average base-flow }\end{array}$} & \multirow{2}{*}{$\begin{array}{c}\text { Difference in } \\
\text { average BFI }\end{array}$} \\
\hline & All years & 1970-99 & All years & $1970-99$ & & & \\
\hline Bois Brule River at Brule & 149 & 152 & 0.869 & 0.873 & $5 \%$ & $2 \%$ & $0.46 \%$ \\
\hline Fox River at Berlin & 941 & 1,127 & .822 & .872 & $78 \%$ & $20 \%$ & $6.08 \%$ \\
\hline Sheboygan River at Sheboygan & 115 & 146 & .474 & .511 & $87 \%$ & $27 \%$ & $7.81 \%$ \\
\hline
\end{tabular}


lands, lakes, and other open water results in overestimation of base flow based on application of hydrographseparation methods. The relation of BFI in this manner makes it possible to (1) extrapolate estimates of BFI to ungaged areas, and (2) differentiate the component of base flow that results from ground-water discharge from the component that results because of delayed flow through surface-water features.

Precipitation that is not returned to the atmosphere by evapotranspiration either flows across the ground surface - discharging directly into wetlands, lakes, and rivers - or infiltrates into the ground surface - recharging the ground-water system and ultimately resulting in ground-water discharge that contributes to base flow. The partitioning of precipitation between runoff and infiltration is regulated by the capacity of the groundwater system to receive and transmit water. This partitioning is a function of landscape attributes and the characteristics of the materials in the shallow subsurface where the subsurface properties are the principal constraint (Piggott and others, 2001). Coarse-textured unconsolidated sediments and permeable and fractured bedrock are typically associated with above average infiltration, whereas fine-textured unconsolidated sediments and low-permeability bedrock are typically associated with above average surface runoff. The nature of the subsurface materials of the Great Lakes Basin can be determined directly using information such as records of water-well construction, or indirectly using geological mapping data. Using water-well construction records to determine the nature of subsurface materials is difficult and costly to assemble across multiple States and provinces. Using geological mapping data for this purpose is not as accurate locally as using water-well records but is more feasible. Geological mapping data reported by Ontario Geological Survey (2000) and Soller (1998) were used in this study.

The component of streamflow from surface runoff is typically more rapidly varying than the component from ground-water discharge and, therefore, base-flow data are frequently used to assess ground-water discharge. However, flow through wetlands, lakes, and other open water slows the surface-runoff component and results in streamflow that is difficult or impossible to differentiate from base flow resulting from ground-water discharge. Surface-water features are prominent in various portions of the study area and are, therefore, a means of differentiating the source of the calculated base flow is required.

\section{G-Model Development}

The G Model is a variation of the relation of base flow to geology reported by Piggott and others (2002). Here, BFI is approximated by using the proportions of surficial-geology classes within the areas that are upstream of the gages. In this study, five surficial-geology classes were defined for the study areas in gaged and ungaged areas. These classes are listed below.

- Bedrock

- Tills

- Organic sediment

- Coarse-textured sediment

- Fine-textured sediment

Surface-water features were also defined throughout the study area for use with the G-SW model described below.

Each surficial-geology class was assigned a value of BFI and the average BFI for the watershed is based on the relative distribution of each class within the watershed. It is assumed when using this model that groundwater discharge is most closely related to surficial geology, and that the averaged values of BFI (determined from either the $\mathrm{G}$ Model or from hydrograph separation) approximate the portion of streamflow that is the result of ground-water discharge. G-Model results for a given gaged watershed can then be directly compared to the value calculated using hydrograph separation. The mathematical statement of the G Model is

$$
\mathrm{y}_{g, i}=\sum_{j} \mathrm{~A}_{g, i, j} \mathrm{x}_{g, j}
$$

where $\mathrm{y}_{g, i}$ is the value of BFI for watershed $i$ that results because of surficial geology and reflects ground-water discharge, $\mathrm{x}_{g, j}$ is the value of BFI for geologic class $j$, and $\mathrm{A}_{g, i, j}$ is the proportion of geologic class $j$ within watershed $i$, expressed as a decimal between 0 and 1 . Equation 1 constitutes the G Model.

\section{G-SW Model Development}

To incorporate the effect of surface water on observed base flow, the proportion of surface-water features within a watershed is also considered in the G-SW Model. The complement of the averaged value of BFI (one minus the averaged value) approximates the portion of streamflow that results because of surface runoff and is attenuated relative to the proportion of surfacewater features within the watershed. This approximation results in an estimate of BFI because of both groundwater discharge and the effect of surface-water features. Attenuation of the surface-runoff component is represented using

$$
1-\mathrm{y}_{a, i}=\mathrm{f}\left(\mathrm{A}_{w, i}\right)\left(1-\mathrm{y}_{g, i}\right),
$$

where $\mathrm{y}_{a, i}$ is the apparent value of BFI for watershed $i$ that can be compared to the value calculated using hydrograph separation, $\mathrm{A}_{w, i}$ is the proportion of surfacewater features within the watershed expressed as a deci- 
mal between 0 and 1 , and $\mathrm{f}\left(\mathrm{A}_{w, i}\right)$ is an attenuation function. The apparent value of BFI can be stated directly as

$$
\mathrm{y}_{a, i}=1-\mathrm{f}\left(\mathrm{A}_{w, i}\right)\left(1-\mathrm{y}_{g, i}\right),
$$

and the suggested form of the attenuation function is

$$
\mathrm{f}\left(\mathrm{A}_{w, i}\right)^{w}=\mathrm{e}^{-\mathrm{x} \mathrm{A}_{w, i}}
$$

where $\mathbf{x}_{w} \geq 0$ is a parameter that regulates the attenuation. This form of the function was derived using streamflow-modeling results for watersheds with varying proportions of surface-water features and on the average relation between the calculated values of BFI and the corresponding proportions of surface-water features.

\section{Model Coefficents and Attenuation Function Parameters}

The values of BFI for the surficial-geology classes and the parameter in the attenuation function were calculated by comparing the estimated and calculated BFI values, specifically by minimizing the error function

$$
\mathrm{E}=\sum_{\mathrm{i}}\left|\mathrm{y}_{g, i} *-\left(1-\mathrm{e}^{-\mathrm{x}_{w}} \mathrm{~A}_{w, i}\left(1-\sum_{\mathrm{j}} \mathrm{A}_{g, i, j} \mathrm{x}_{g, j}\right)\right)\right|
$$

with respect to $\mathrm{x}_{g, j}$ and $\mathrm{x}_{w}$ using a non-linear optimization algorithm, where $\mathrm{y}_{g, i} *$ are the values of BFI calculated using the hydrograph-separation information. This process was followed using the hydrograph-separation results from each of the six hydrograph-separation methods used in this study. Therefore, the G Model and G-SW Model have coefficients that vary slightly depending upon which hydrograph-separation method was used.

For example, consider HUC watershed 04060102, Muskegon River, Michigan. The mathematical form of the G Model calibrated with PART hydrograph-separation data was determined to be

$$
\begin{aligned}
& (\text { Bedrock } * 0.78)+(\text { Coarse } * 0.89)+(\text { Fine } * 0.25) \\
& +(\text { Organic } * 0.09)+(\text { Till } * 0.52) .
\end{aligned}
$$

The G-SW Model was determined to be

$$
\begin{aligned}
& 1-\mathrm{e}^{\wedge}(-1 * 2.96 * \text { proportion of surface water }) * \\
& (1-\mathrm{G} \text { Model solution). }
\end{aligned}
$$

The coefficients in the equations below are the proportions of each respective surficial-geology class occurring within HUC watershed 04060102, Muskegon River, Michigan. The G Model yields

$$
\begin{aligned}
& (0.00 * 0.78)+(0.54 * 0.89)+(0.00 * 0.25)+ \\
& (0.00 * 0.09)+(0.45 * 0.52)=0.71
\end{aligned}
$$

Similarly, the G-SW Model yields

$$
1-\mathrm{e}^{\wedge}(-1 * 2.96 * 0.19) *(1-0.71)=0.83 .
$$

In this example, the BFI for the Muskegon River, Michigan, HUC watershed 04060102 using the G Model is estimated to be 0.71 . This estimate is meant to approximate the proportion of streamflow originating from ground-water discharge. Also in this example, the BFI using the G-SW Model is estimated to be 0.83 . This estimate is meant to incorporate the effect of surface-water features that appear to be base flow on hydrographs (fig. 2 ). In other words, the G-SW Model result of 0.83 represents what would likely result if a long-term hydrographseparation analysis was performed using streamflow data collected at the downstream end of this HUC watershed with the PART hydrograph-separation method. For comparison, using PART and the streamflow record on the most downstream gage on the Muskegon River retained for model development (04122000), the BFI was estimated to be 0.75 .

\section{Conversion from Base-Flow Index to Base Flow}

Total runoff for each 8-digit HUC and tertiary watershed was estimated as an area weighted average of length of record streamflow observed in nearby gaged watersheds. Total runoff for this period was then multiplied by long-term average BFI estimates to calculate total base flow (volume/time).

It was determined not to be necessary to recalculate total runoff and base flow for each HUC and tertiary watershed using truncated streamflow data to match a specific time period (for example, average climate data are commonly stated as year 2000, 30-year climate normals). To evaluate the effect of climate variability on streamflow, average streamflow was recalculated for 555 gages in Ontario and 1936 gages in the U.S. using only 1971-2000 streamflow data and compared to lengthof-record total streamflow at those same gages. Results show no systematic difference in total runoff calculated for the two periods and a regression between the two datasets reveals an almost perfect 1:1 relation (fig. 4). In other words, recalculating total runoff in each HUC and tertiary watershed using 1971-2000 streamflow data would have a negligible effect on estimates of runoff and the conversion of BFI to base flow. This result is not to say that there are no trends in the streamflow record, just that 1971-2000 average streamflow is not noticeably different from length of record average streamflow at these gages. Therefore, no further attempt was made to relate base-flow estimates to a specific period of time. It must be stated that whereas BFI is much less variable through time than base flow, BFI is not perfectly stable. Using 


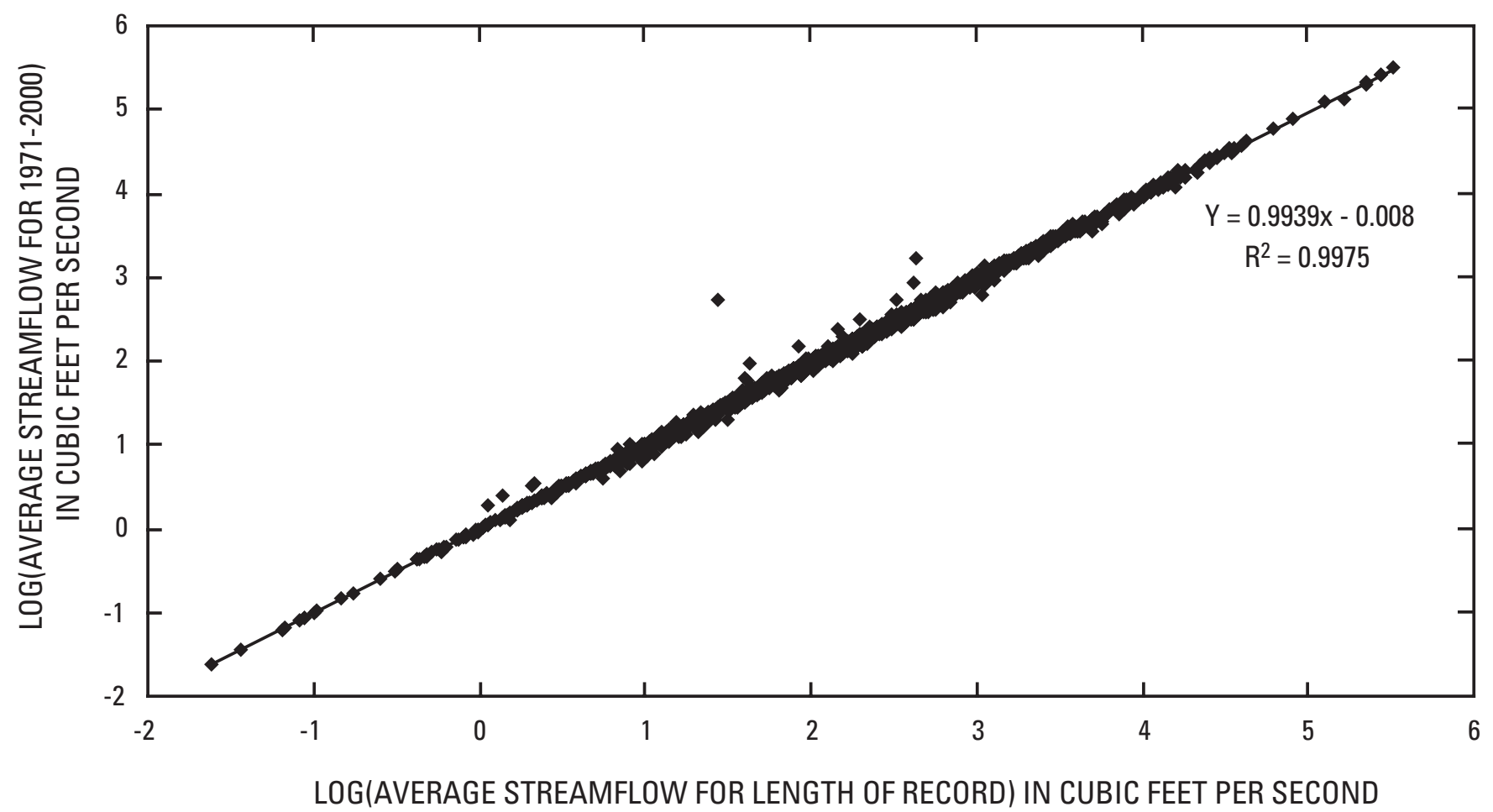

Figure 4. Comparison of 1971 - 2000 average streamflow to length of record average streamflow at 555 streamflow gages in Ontario and 1936 streamflow gages in the eight Great Lakes States of Illinois, Indiana, Michigan, Minnesota, New York, Ohio, Pennsylvania, and Wisconsin. ( $\mathrm{R}^{2}$, coefficient of determination).

this method may result in some amount of uncertainty in base-flow estimates.

To develop area weighted averages of runoff, a value of runoff was first assigned to each gaged watershed in terms of depth of watershed per year, termed a "flow ratio". Flow ratios are simply a unit conversion of streamflow from the commonly used cubic feet per second $\left(\mathrm{ft}^{3} / \mathrm{s}\right)$ to [feet (ft) times watershed area in square feet $\left.\left(\mathrm{ft}^{2}\right)\right] /$ year. The gaged watersheds were then intersected with 8-digit HUC and tertiary watersheds. A weight $(w)$ was determined for each gaged watershed that fell within a given HUC or tertiary watershed and given as

$$
\begin{aligned}
\mathrm{w}= & \text { Intersected area } /(\text { Ungaged area }+ \text { Gaged } \\
& \text { area }- \text { Intersected area }) .
\end{aligned}
$$

The weights were then applied to the flow ratios for each of the gaged watersheds (i) within a given HUC or tertiary watershed to determine the flow ratio for each respective HUC or tertiary watershed and given as

$$
\mathrm{F}_{\mathrm{HUC}}=\sum\left(\mathrm{w}_{(i)} * \mathrm{~F}_{(i)}\right) / \sum w_{(i)},
$$

where $\mathrm{F}_{\mathrm{HUC}}$ is the flow ratio of each HUC and tertiary watershed, $\mathrm{w}_{(i)}$ is the weight of gage $\mathrm{i}$, and $\mathrm{F}_{(i)}$ is the flow ratio of gage i. Total runoff was determined by multiplying the calculated flow ratio by the area of the HUC or tertiary watershed. Base flow was then determined by multiplying modeled BFI by total runoff for each HUC or tertiary watershed.

Not every HUC and tertiary watershed contained a gaged area. There were 20 HUC and 3 tertiary watersheds that did not contain a gaged area. To estimate runoff in 13 of the HUC watersheds and two of the tertiary watersheds, inverse-distance squared weight of BFI values of surrounding HUC or tertiary watersheds was used and given as

$$
\mathrm{F}_{H U C}=\sum\left[\left(1 / \mathrm{d}_{H}^{2}\right) * \mathrm{~F}_{H}\right] / \sum\left(1 / \mathrm{d}_{H}^{2}\right),
$$

where $\mathrm{d}_{H}$ is the distance to the geographical center of adjacent $\mathrm{HUC}$ or tertiary watershed $\mathrm{H}$ and $\mathrm{F}_{H}$ is the flow ratio of adjacent HUC or tertiary watershed $\mathrm{H}$.

The remaining seven HUC watersheds that did not contain a gaged area and had incomplete flow-ratio data of surrounding HUC watersheds were all located in the 
snow shadow areas south and east of Lake Erie and Lake Ontario. Flow ratios for six of these seven watersheds were determined by assuming the flow ratio of similar watersheds in the Lake Erie snow shadow where flow ratios were known. The flow ratio for the one remaining HUC watershed (04140102, also in the Lake Ontario snow shadow) was estimated using one adjacent watershed and one watershed in the Lake Erie snow shadow as per professional judgment. The one tertiary watershed without a gaged area or surrounding tertiary watershed with flow-ratio data was 2CG, Manitoulin Island, Ontario. It was assumed that the flow ratio for 2CG was equal to 2FA (Bruce Peninsula, Ontario) because of their similar geology of Paleozoic carbonate bedrock and proximity to Lake Huron (fig. 1).

\section{Base Flow in the Great Lakes Basin}

Study results of base flow are presented by gaged and ungaged areas. A basic overview of the results is provided below. A complete listing of estimated BFI, base flow, and total streamflow is provided in appendix A (4 CD-ROMs, inside back cover).

\section{Gaged Areas}

Results of the hydrograph-separation analysis indicate a large degree of variation in BFI among individual gages (fig. 5). Among the 959 gages selected for developing the regression equations and using all six hydrograph-separation methods, BFI values ranged from 0.089 to 0.978 . In general, the lowest BFI values resulted

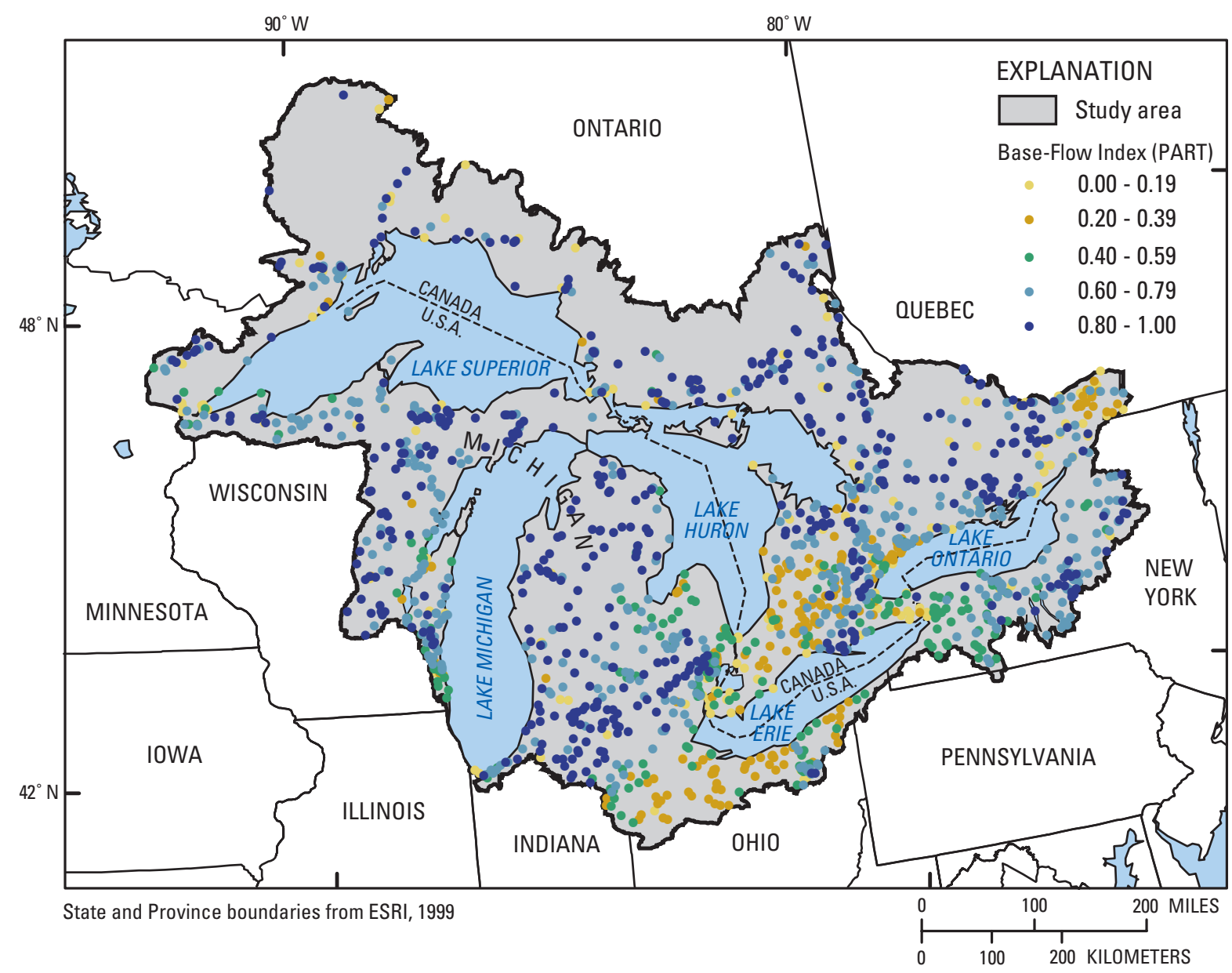

Figure 5. Results of base-flow separation using PART for streamflow records at streamflow-gaging stations within the study area. 


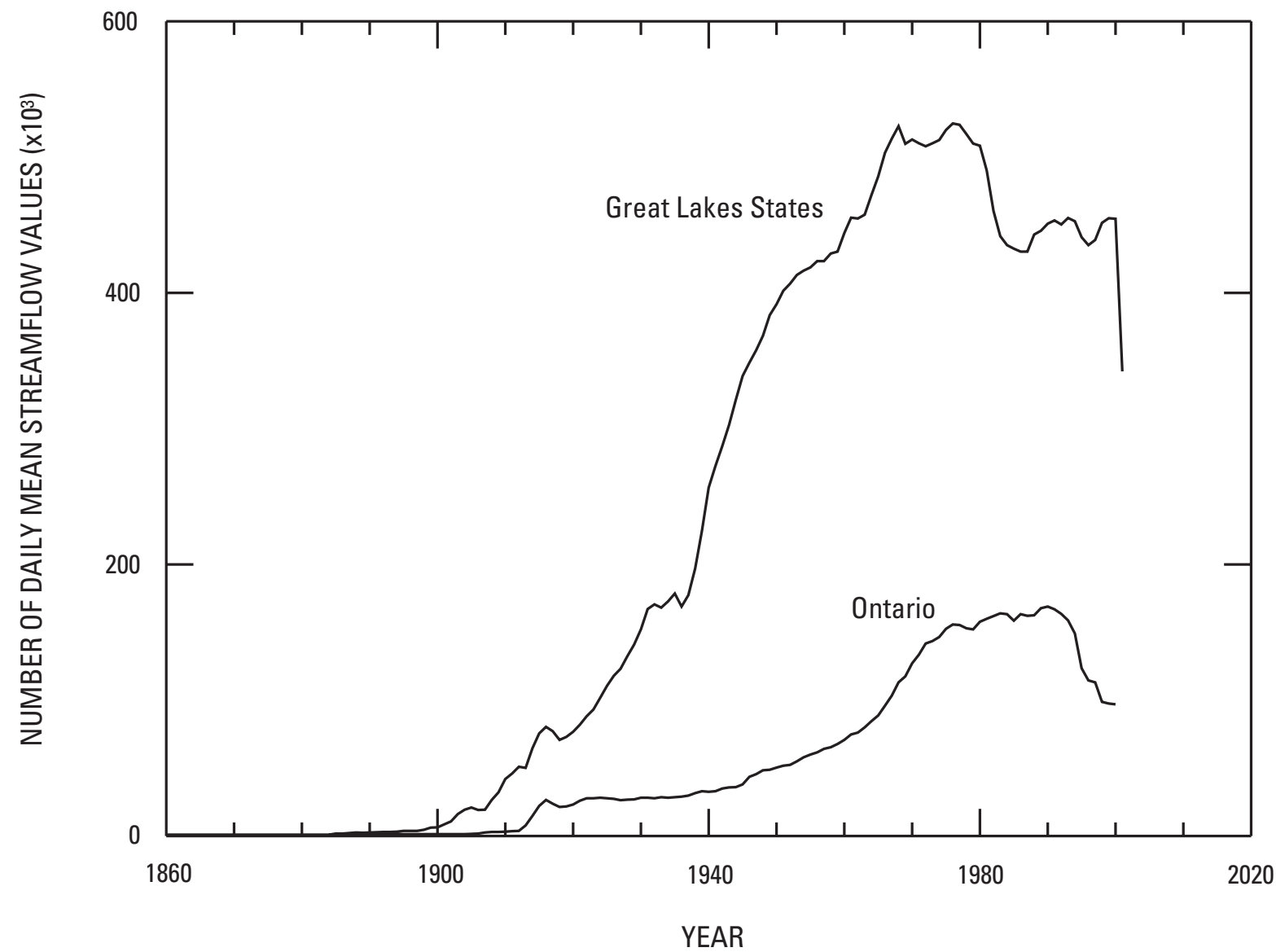

Figure 6. Temporal distribution of daily streamflow data in Ontario, Canada and the eight Great Lakes States of Illinois, Indiana, Michigan, Minnesota, New York, Ohio, Pennsylvania, and Wisconsin, 1860-2001. [The abrupt drop in the number of values at the end of the Great Lakes States record results from using slightly different periods of record between the United States and Canada. United States records continue through September 2001, while Canadian records continue through December 2001.]

Table 2. Base-flow index statistics for streamflow records of streamflow-gaging stations in the Great Lakes Basin based on six hydrograph-separation methods (Base-flow index is dimensionless).

\begin{tabular}{lrrrrrr}
\hline & \multicolumn{7}{c}{ Hydrograph-separation method } \\
\cline { 2 - 7 } Statistic & UKIH & PART & BFLOW & HYSEP 1 & HYSEP 2 & HYSEP 3 \\
\hline Minimum & 0.09 & 0.09 & 0.09 & 0.26 & 0.26 & 0.22 \\
Maximum & .97 & .98 & .92 & .97 & .97 & .97 \\
Average & .54 & .70 & .48 & .70 & .70 & .62 \\
\hline
\end{tabular}


in the south-central part of the basin, particularly in the southwestern Lake Erie Basin. The highest BFI values resulted in the Lake Michigan and Lake Superior Basins, as well as the northern half of the Lake Huron Basin. Basic BFI statistics of the hydrograph-separation results for all 3,936 gages considered in this study are given in table 2 . The temporal distribution of daily streamflow data used in the analyses is illustrated in figure 6.

Results of the hydrograph separations also illustrate variation among the six hydrograph-separation methods used in the analysis (table 2). For individual gages, the average range of BFI values produced using the six methods was 0.24 . BFI values were much higher at some individual gages. For example, BFI calculated for gage 04085068, Ashwaubenon Creek near Little Rapids, WI, was 0.76 when calculated using HYSEP 2, and was 0.13 when calculated using BFLOW. BFI estimates were generally highest and most consistent using the HYSEP 1, HYSEP 2, and PART methods. Average BFI for all 959 gages using these three methods was 0.70 . BFI estimates using the BFLOW method averaged 0.48 and were generally the lowest of all six methods. The HYSEP 3 and UKIH methods resulted in values between these extremes, with BFI results averaging 0.62 and 0.54 , respectively. Results of hydrograph separation using six methods are summarized in appendix A.

\section{Correlation of Base-Flow Index with Model Predictions}

Performance of the G Model is demonstrated by comparing the calculated $\mathrm{Y}_{x, i} \mathrm{BFI}$ values to estimated $\mathrm{Y}_{g, x, i}$ values determined using equation 1 , where $\mathrm{Y}_{x, i}$ is the BFI calculated at gage $\mathrm{x}$ using hydrograph-separation method $\mathrm{i}$ and $\mathrm{Y}_{g, x, i}$ is the BFI predicted with the $\mathrm{G}$ Model at gage $\mathrm{x}$ using hydrograph-separation method $\mathrm{i}$. Depending on which hydrograph-separation method is used, from 44 to 56 percent of the BFI values predicted with the G Model are within $\pm 0.1 \mathrm{BFI}$, or 10 percent, of BFI calculated by hydrograph-separation analysis. From
80 to 89 percent of estimated values are within $0.2 \mathrm{BFI}$, or 20 percent, of BFI calculated by hydrograph-separation analysis (table 3 ). This result compares favorably with the 0.24 average range of BFI values calculated with the six hydrograph-separation methods used in this study and indicates that the uncertainty among hydrograph-separation methods is greater than the uncertainty of model results.

Estimates obtained with the G-SW Model relate better to BFI calculated for individual gages because the GSW Model estimates the effect of surface water that can increase BFI at a given gage. The G-SW Model performance is demonstrated by comparing the calculated $\mathrm{Y}_{x, i}$ BFI values to estimated $\mathrm{Y}_{g s w, x, i}$ values determined using equations 3 and 4, where $\mathrm{Y}_{g s w, x, i}$ is the BFI predicted with the G-SW Model at gage x using hydrograph-separation method i. Depending on the separation method used, from 56 to 69 percent of the estimated values are within $0.1 \mathrm{BFI}$, or 10 percent, of the permissible range and from 88 to 94 percent of estimated values are within $0.2 \mathrm{BFI}$, or 20 percent, of BFI calculated by hydrograph analysis (table 3 ). This result compares favorably with the 0.24 average range of BFI values calculated with the six hydrograph-separation methods used in this study and indicates that the uncertainty among methods of hydrograph separation is greater than the uncertainty of model results.

\section{Ungaged Areas}

Model predictions of BFI in individual 8-digit HUC and tertiary watersheds indicate a similar spatial variation across the Great Lakes Basin to BFI estimated at individual gages using hydrograph-separation methods (figs. 5 and 7). In general, the lowest BFI values resulted in the south-central part of the basin, particularly in the southwestern Lake Erie Basin. The highest BFI values resulted in the Lake Michigan and Lake Superior Basins, as well as the northern half of the Lake Huron Basin. The highest BFI values predicted with the G Model

Table 3. Percentage of model predictions for gaged watersheds in the study area within 0.1 and 0.2 of base-flow index (BFI) values determined from hydrograph-separation analyses (Base-flow index is dimensionless).

\begin{tabular}{cccccccc}
\hline & & \multicolumn{5}{c}{ Hydrograph-separation method } \\
\cline { 3 - 7 } Model & BFI & UKIH & PART & BFLOW & HYSEP 1 & HYSEP 2 & HYSEP 3 \\
\hline Geology $(\mathrm{G})$ Model $\left(\mathrm{Y}_{\mathrm{g}, \mathrm{x}}, \mathrm{i}\right)$ & \pm 0.1 & 44 & 47 & 54 & 54 & 53 & 56 \\
& \pm .2 & 80 & 83 & 89 & 88 & 88 & 89 \\
\hline Geology-Surface Water $(\mathrm{G}-\mathrm{SW})$ & \pm .1 & 56 & 63 & 61 & 69 & 69 & 66 \\
Model $\left(\mathrm{Y}_{\mathrm{gsw}}, \mathrm{x}, \mathrm{i}\right)$ & \pm .2 & 88 & 91 & 92 & 94 & 93 & 93 \\
\hline
\end{tabular}



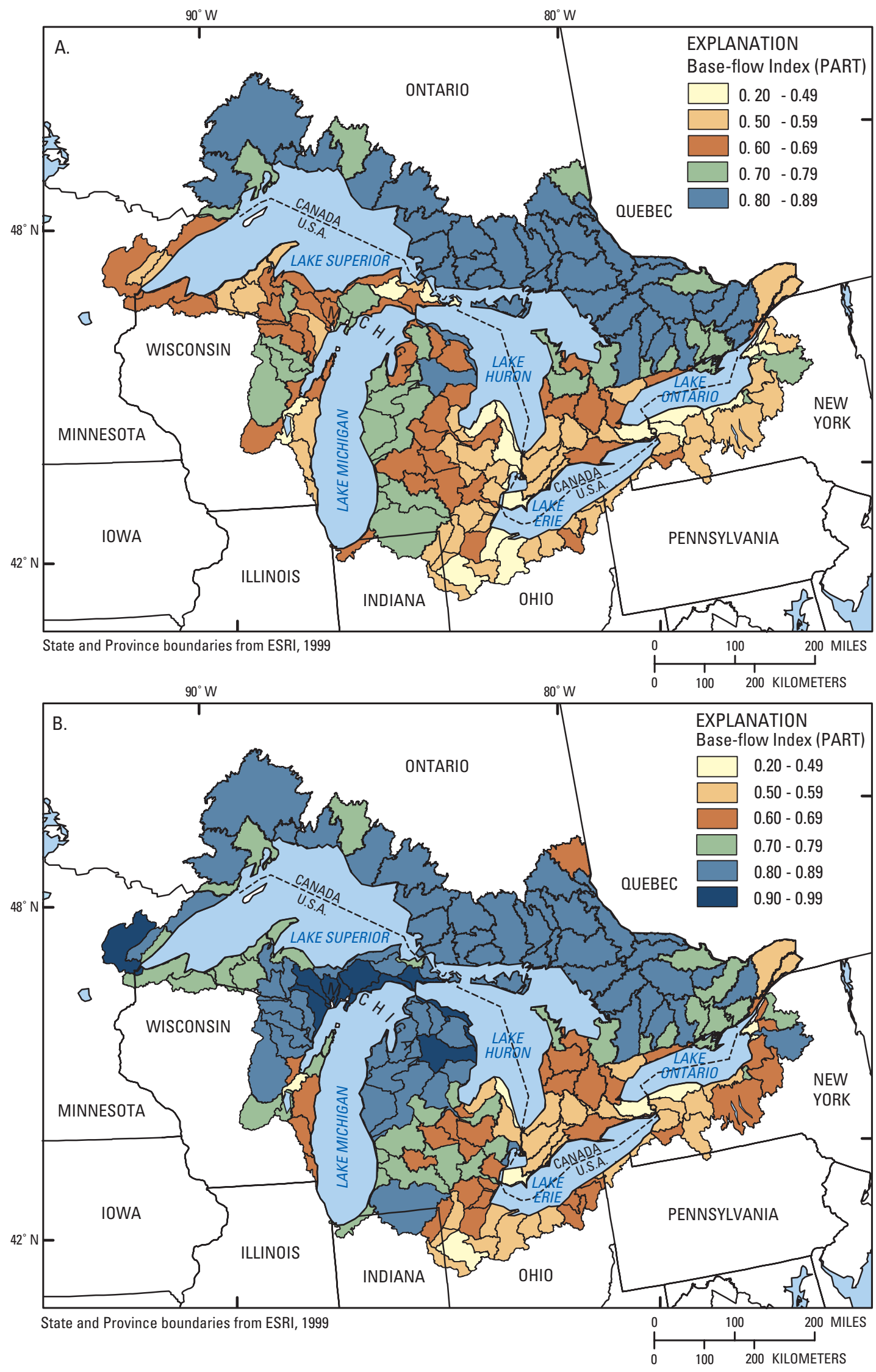

Figure 7. Base-flow indexes for 8-digit Hydrologic Unit Codes in the U.S. and the tertiary watersheds in Canada based on the A) G Model and B) G-SW Model calibrated using PART hydrograph analysis results. 
resulted in the northern Lower Peninsula of Michigan, whereas the highest G-SW Model estimates resulted in the eastern Upper Peninsula of Michigan.

The range in model-simulated BFI values was less than the range in BFI calculated at individual gages using hydrograph separation. Among the 169 predicted watersheds, BFI estimated with the G Model averaged 0.55 and ranged from 0.11 to 0.83 . BFI estimated with the G-SW Model averaged 0.64 and ranged from 0.19 to 0.95 . A summary of BFI estimates for each HUC and tertiary watershed is provided in table 4 (at the back of the report) and a summary of base-flow estimates is found in appendix A.

Many of the studies relating low-flow indices to watershed characteristics found that geology is one of the most significant variables in these relations (Armentrout and Wilson, 1987; Cervione and others, 1993; Bingham, 1986; Ries, 1994; Lacey and Grayson, 1998; Tague and Grant, 2004; Piggott and others, 2002; Yokoo and others, 2001; Winter, 2001; Mazvimavi and others, 2004). Additional studies have shown that slope can also be an important variable in estimating low-flow characteristics (Gustard and others, 1989; Nathan and McMahon, 1990; Vogel and Kroll, 1992; Burn and Boorman, 1993; Garcia-Martino and others, 1996; Sefton and Howarth, 1998; Piggott and others, 2005; Berger and Entekhabi, 2001; Mazvimavi and others, 2004). Statistical analyses performed during this study had also indicated that slope is correlated to BFI and should be included in the model. Currently (2005), the G and G-SW Models are physically based with the signs and magnitudes of the coefficients realistically representing the water-transport capacity of each surficial-geology class. Developing a regressionally based model would allow for the incorporation of slope and improve the predictive model capacity (Armentrout and Wilson, 1987; Smakhtin, 2001), however, the model will no longer represent the physical hydrogeologic system as the coefficients will no longer have any realistic meaning. Time constraints prevented the development of a physically based model incorporating slope. Therefore, ungaged watershed analyses were performed with the simpler $\mathrm{G}$ and G-SW Models as opposed to using a regressionally based model.

Regression models for low-flow indices, such as 7Q2 and 7Q10 (7-day average minimum flow during 2and 10-year periods, respectively), have reported strong relations with watershed characteristics such as deciduous or conifer tree type, average summer basin temperature, and slope (Flynn, 2003). However, there has been limited success in other studies relating BFI to watershed characteristics with coefficients of determination $\left(\mathrm{R}^{2}\right)$ ranging from $<0.5$ to 0.83 (table 5). For the G-SW Model, $\mathrm{R}^{2}$ values ranged from 0.504 to 0.549 , with an average of 0.530 depending on which hydrograph-separation method was used to develop the model. This $\mathrm{R}^{2}$ value is statistically stronger than that of Bullock (1988) and Gustard and others (1989) but is statistically weaker than Nathan and McMahon (1992), Lacey and Grayson (1998), Mazvimavi (2003), and Mazvimavi and others (2004). Standard error (SE) in this study, an average of 0.1132 , falls within the range of SE for the other studies (from 0.08 to 0.19). It is important to note that Nathan and McMahon (1992), Lacey and Grayson (1998), Mazvimavi (2003) and Mazvimavi and others (2004) used lumped regression models in their analysis. Inclusion of additional variables and altering the present study model from a physically based to a lumped regression model

Table 5. Regression model statistics determined in previous studies used in relating base-flow index to watershed variables in the Great Lakes Basin..

$\left[\mathrm{R}^{2}\right.$, Coefficient of determination; SE, standard error of estimate; BFI, base-flow index; <, less than; \%, percent; N/A, not applicable; , approximately.]

\begin{tabular}{|c|c|c|c|}
\hline Study & Variables Used & $\mathbf{R}^{2}$ & SE \\
\hline Mazvimavi (2003) & $\begin{array}{l}\text { BFI, Slope, Mean annual precipitation, Wooded grassland and Grassland } \\
\text { cover, Kalahari sand cover }\end{array}$ & $.63-.75$ & N/A \\
\hline Lacey and Grayzon (1998) & $\begin{array}{l}\text { BFI, Area, Elevation, Potential evaporation, Forest cover, Sedimentary } \\
\text { bedrock cover, Rainfall, Length of stream }\end{array}$ & .72 & .19 \\
\hline Bullock (1988) & $\begin{array}{l}\text { BFI, Soil types, Mean annual precipitation, Proportion of dams, Area, } \\
\text { Slope }\end{array}$ & .48 & N/A \\
\hline
\end{tabular}


would improve the $\mathrm{R}^{2}$ value; however, G-SW Model $\mathrm{R}^{2}$ values calculated are within the range of values found in other studies. BFI estimates based on the G and G-SW Models are summarized in appendix A.

\section{Model Limitations}

In this study, use of the G and G-SW Models to estimate base flow are limited in various ways. First, both models are based on observations and landscape attributes present within the Great Lakes Basin. Accordingly, both the models and results are applicable only to the basin. The temporal scale of model results is limited to long-term (years to tens of years) averages, and does not reflect seasonal or interannual variation. Also, the spatial scale to which estimates can be made for ungaged areas can not be finer than the density and quality of the streamgage network. For example, a relatively sparse network of usable gages is present in northern Ontario and parts of New York east of Lake Ontario as compared to other parts of the basin. As a consequence, estimates are limited to averages over broad areas, represented by 8 -digit HUC and tertiary watersheds. This level of resolution was applied across the basin to maintain study continuity. Additionally, each model is more useful to specific applications. G Model results are intended to reflect the ground-water component of streamflow. This result is likely to be preferred by some users. Other users will be more interested in the G-SW Model results because the effect of surface-water features is incorporated in this model. Incorporation of these features provides a better estimate of observed base flow in given watersheds. In many instances, G Model estimated base flow is smaller than G-SW Model estimated base flow, particularly in areas with many surface-water features (for example, lakes, wetlands, and beaver ponds) that store water and gradually drain.

Accuracy of model results is limited by various factors. It is uncertain which hydrograph-separation method is best for model simulation. Base-flow estimates of individual streamflow records using the six methods tested vary an average of $0.24 \mathrm{BFI}$. Also, model results may also be limited by constraining the surficial geology to five classes. Many variables were found statistically to contribute to base flow, but using common datasets in all areas within the basin precluded incorporating these variables in model simulation. The application of the two models to all areas of the basin may also affect modelsimulation accuracy. It could be possible to separate this analysis by region within the basin and develop separate regression models for each region. Smakhtin (2001) found this approach beneficial in his analysis. However, this approach was not used in this study because it was considered important to apply the same methods for the entire basin. Accuracy of base-flow estimates is also limited by the accuracy of total runoff estimates; total runoff estimates were based on area-runoff ratios. Dataset availability and study-time restrictions prevented the calculation of runoff using other methods.

Another limitation is the presentation of model results. Both models consider landscape attributes within a given watershed to estimate base flow at the downstream end of the watershed. It was decided that the best way to represent this result was to color code the entire watershed. This method fails to convey the spatially variable nature of base flow. It is important to note that other approaches to display these results are available.

\section{Suggestions for Possible Future Study}

Long-term trend analysis of base flow using these study results is a logical approach to evaluate the effect of various factors, such as changing land and water use and climate change, on ground-water resources in the Great Lakes Basin. Also, validation of present and new methods of hydrograph separation is needed to improve base-flow estimates. Evaluating the effect of watershed size on base flow should also be pursued. Finally, further research could focus on reducing the scale at which estimates of base flow can be made. Incorporating additional variables, reducing the spatial scope of future models, utilizing denser gage networks, and improving runoff estimates could enable finer resolution of future estimates of base flow in the Great Lakes Basin.

\section{Summary and Conclusions}

Base flow in the Great Lakes and Ottawa and upper St. Lawrence River Basins is defined as the total groundwater discharge to streams that feed into these lakes and water bodies. The estimation of this discharge is important for proper management of these water bodies. Past estimates of base flow in some sub-basins of the Great Lakes have proven useful, but do not extend basin-wide and are believed to be considerably inaccurate for some areas. Therefore, the USGS, in cooperation with Environment Canada's National Water Research Institute and the Great Lakes Protection Fund, began a study in 2002 to more accurately assess base flow in the Great Lakes Basin. The study area includes the portions of Ontario and the eight Great Lakes States that lie within the Great Lakes Basin and Ottawa and upper St. Lawrence River Basins. The study area includes the parts of the eight Great Lakes States and one Canadian Province that lie within the Great Lakes Basin (Illinois, Indiana, 
Michigan, Minnesota, New York, Ohio, Pennsylvania, Wisconsin, and Ontario, Canada). Total land area of the study area is $204,000 \mathrm{mi}^{2}$. Fifty-nine percent of the study area is in the U.S. and 41 percent is in Canada. Average annual precipitation ranges from less than $27 \mathrm{in}$. west of Lake Superior to more than 47 in. east of Lake Ontario.

Hydrograph separations were performed on 3,936 length-of-record daily streamflow datasets from gages in Ontario and the eight Great Lakes States using the hydrograph-separation methods PART, HYSEP 1, 2, and 3, BFLOW and UKIH. Data from 959 selected gages were used to develop two regression models. The Geology $(\mathrm{G})$ Model related base-flow index to the surficial geology of the gaged watersheds and is intended to reflect the ground-water component of streamflow. The Geology-Surface Water (G-SW) Model incorporated the proportion of surface water within the watersheds and is intended to better estimate observed base flow in given watersheds. These regression models were then used to derive estimates of average long-term BFI for all areas in the Great Lakes Basin, and Ottawa and the upper St. Lawrence Rivers Basins.

Results of the hydrograph-separation analysis illustrate geographical trends in base flow throughout the study area, with higher BFI resulting in the Lake Michigan and Lake Superior Basins, as well as the northern half of the Lake Huron Basin. On average, results from each of the six hydrograph-separation methods ranged by 0.24 BFI. When applied to gaged watersheds, the G and G-SW Models predicted observed base flow at individual gages up to 89 percent and 94 percent of the time, respectively, within 0.2 BFI. When applied to the study area at the 8-digit HUC (U.S.) and tertiary watersheds (Canada) scale, highest BFI values predicted with the G Model resulted in the northern Lower Peninsula of Michigan, whereas the highest G-SW Model estimates resulted in the eastern Upper Peninsula of Michigan. The lowest BFI values resulted in the south-central part of the basin, particularly in the southwestern Lake Erie Basin. Statistical analysis indicated that slope is correlated to BFI. Coefficient of determination and standard error values relating BFI to watershed characteristics calculated in this study were within a range reported in other studies.

Suggestions for possible future study include longterm trend base-flow analysis, validation of present and new hydrograph-separation methods, and evaluation the effects of watershed scale on base flow. Also, future estimates could be improved by incorporation additional variables, utilizing denser gage networks, and improving runoff estimates.

\section{Acknowledgments}

The authors appreciate the important contributions of the Ontario Ministry of Natural Resources, the Ontario Ministry of the Environment, and Environment Canada's Meteorological Service of Canada in providing data and information during the course of this study. Additionally, substantial assistance collecting information on National Pollution Discharge Elimination System discharge permits and State dam inventories was provided by personnel with the Environmental Protection Agency, Indiana Department of Natural Resources, Michigan Department of Environmental Quality, New York Department of Environmental Conservation, Ohio Department of Natural Resources, and the Wisconsin Department of Natural Resources. The authors thank Al Rutledge (USGS) and Warren Gebert (USGS-retired) who provided thorough technical reviews of the report and Angel Martin (USGS) who provided an editorial review. 
Table 4. Long-term average base-flow index estimates for each Hydrologic Unit Code (HUC) and tertiary watershed in the Great Lakes Basin. Results are derived using two models, the $\mathrm{G}$ Model, designed to estimate the ground-water component of streamflow and the G-SW Model, designed to estimate the sum of ground-water component of streamflow and the effect of surface-water features within each watershed. Each model was calibrated with base-flow index data derived using six different hydrograph-separation methods, UKIH, PART, BFLOW, HYSEP 1, HYSEP 2, and HYSEP 3, frequently leading to variability in estimates (Base flow is dimensionless).

[G, G Model results; G-SW, G-SW Model results; HUC, Hydrologic Unit Code.]

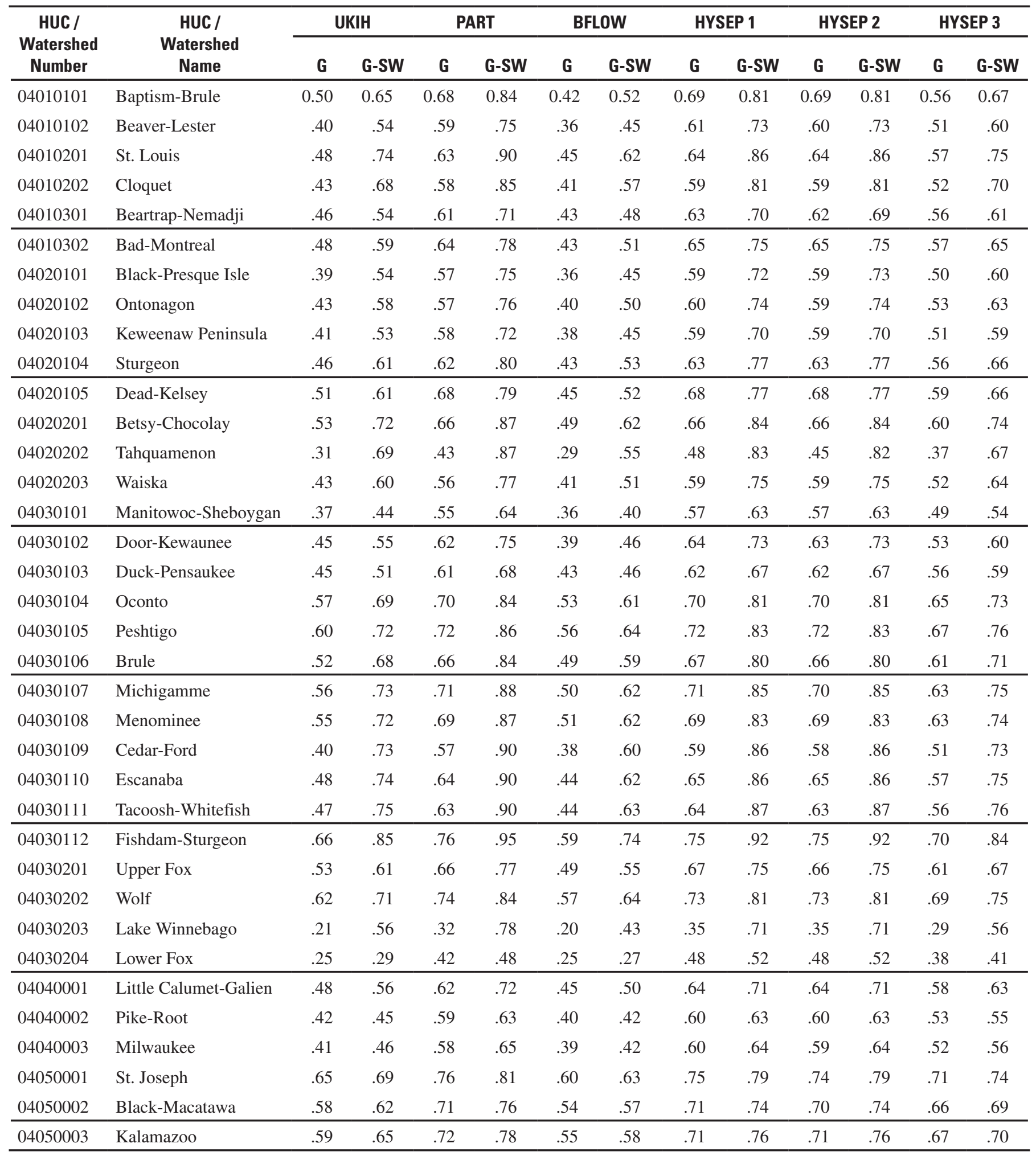


Table 4 (continued). Long-term average base-flow index estimates for each Hydrologic Unit Code (HUC) and tertiary watershed in the Great Lakes Basin. Results are derived using two models, the G Model, designed to estimate the ground-water component of streamflow and the G-SW Model, designed to estimate the sum of ground-water component of streamflow and the effect of surface-water features within each watershed. Each model was calibrated with base-flow index data derived using six different hydrograph-separation methods, UKIH, PART, BFLOW, HYSEP 1, HYSEP 2, and HYSEP 3, frequently leading to variability in estimates (Base flow is dimensionless).

[G, G Model results; G-SW, G-SW Model results; HUC, Hydrologic Unit Code.]

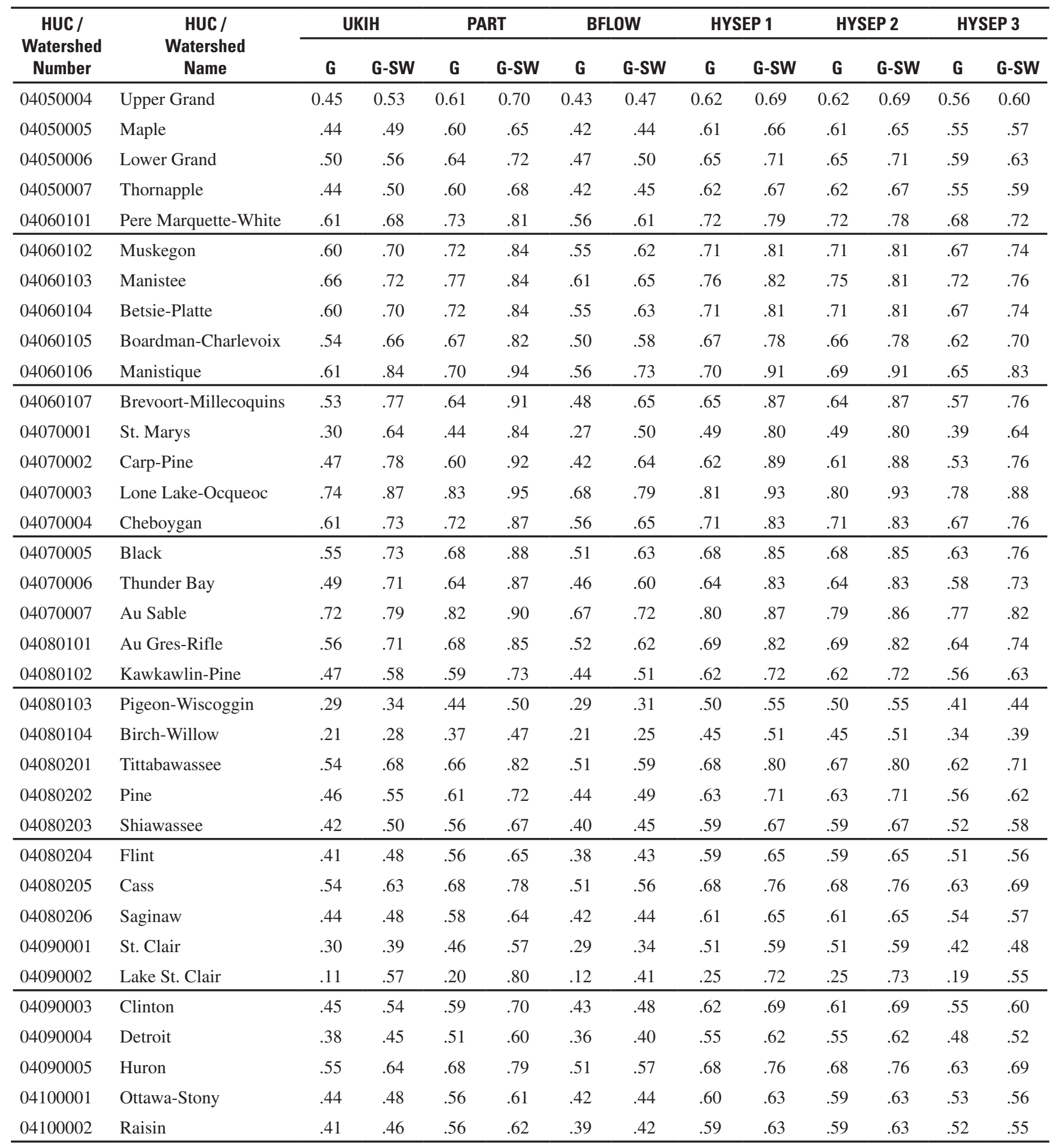


Table 4 (continued). Long-term average base-flow index estimates for each Hydrologic Unit Code (HUC) and tertiary watershed in the Great Lakes Basin. Results are derived using two models, the G Model, designed to estimate the ground-water component of streamflow and the G-SW Model, designed to estimate the sum of ground-water component of streamflow and the effect of surface-water features within each watershed. Each model was calibrated with base-flow index data derived using six different hydrograph-separation methods, UKIH, PART, BFLOW, HYSEP 1, HYSEP 2, and HYSEP 3, frequently leading to variability in estimates (Base flow is dimensionless).

[G, G Model results; G-SW, G-SW Model results; HUC, Hydrologic Unit Code.]

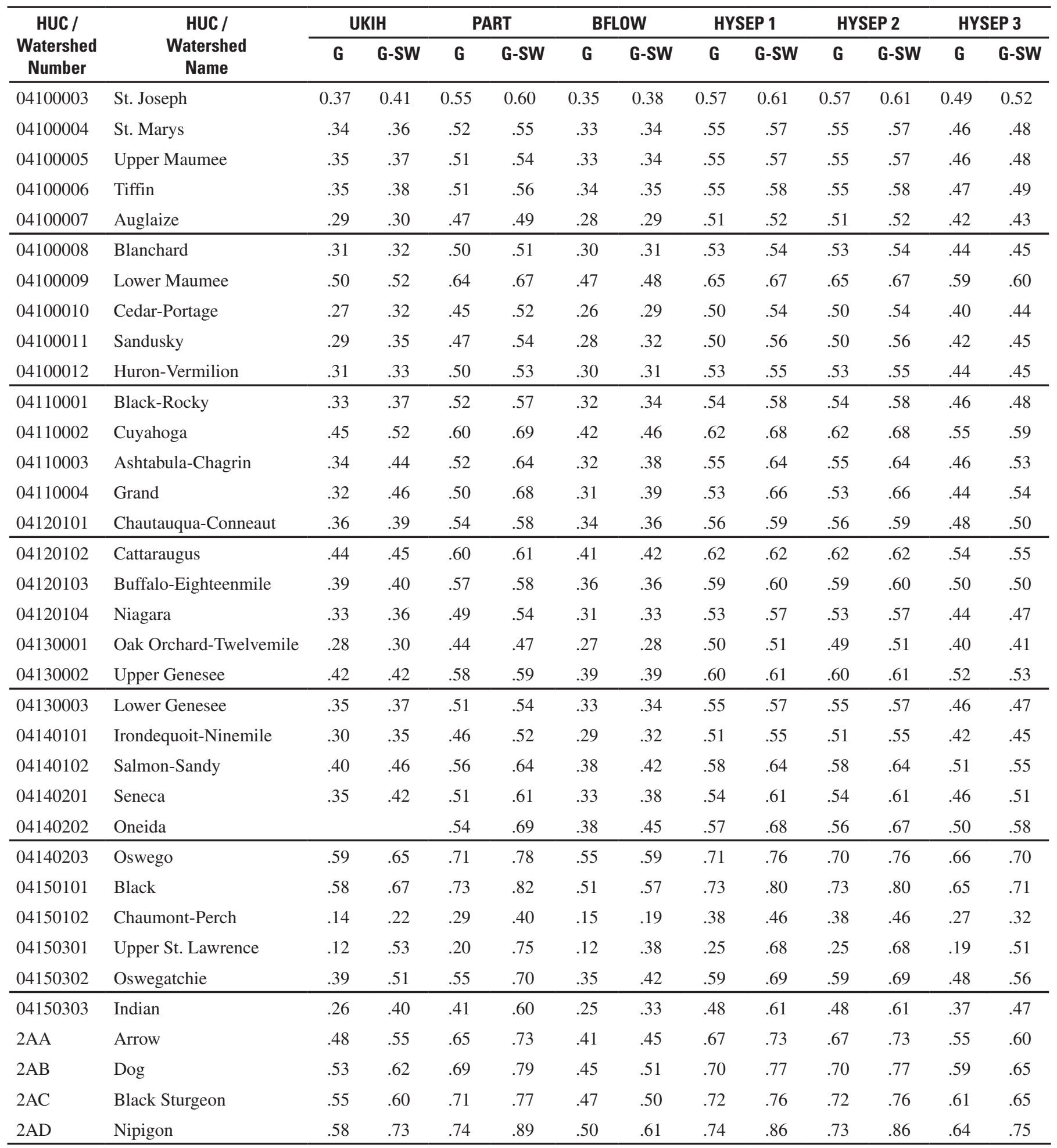


Table 4 (continued). Long-term average base-flow index estimates for each Hydrologic Unit Code (HUC) and tertiary watershed in the Great Lakes Basin. Results are derived using two models, the G Model, designed to estimate the ground-water component of streamflow and the G-SW Model, designed to estimate the sum of ground-water component of streamflow and the effect of surface-water features within each watershed. Each model was calibrated with base-flow index data derived using six different hydrograph-separation methods, UKIH, PART, BFLOW, HYSEP 1, HYSEP 2, and HYSEP 3, frequently leading to variability in estimates (Base flow is dimensionless).

[G, G Model results; G-SW, G-SW Model results; HUC, Hydrologic Unit Code.]

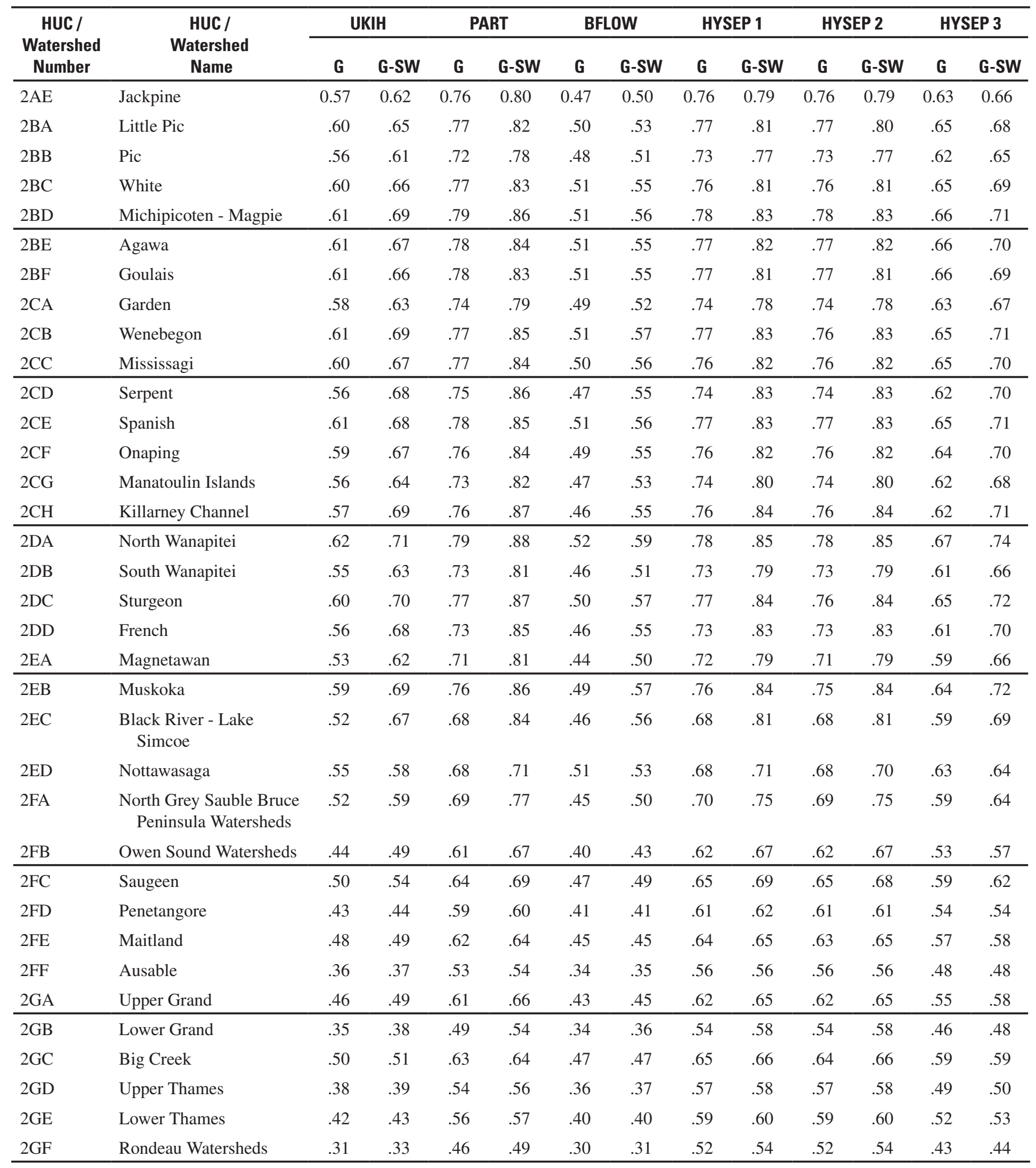


Table 4 (continued). Long-term average base-flow index estimates for each Hydrologic Unit Code (HUC) and tertiary watershed in the Great Lakes Basin. Results are derived using two models, the $\mathrm{G}$ Model, designed to estimate the ground-water component of streamflow and the G-SW Model, designed to estimate the sum of ground-water component of streamflow and the effect of surface-water features within each watershed. Each model was calibrated with base-flow index data derived using six different hydrograph-separation methods, UKIH, PART, BFLOW, HYSEP 1, HYSEP 2, and HYSEP 3, frequently leading to variability in estimates (Base flow is dimensionless).

[G, G Model results; G-SW, G-SW Model results; HUC, Hydrologic Unit Code.]

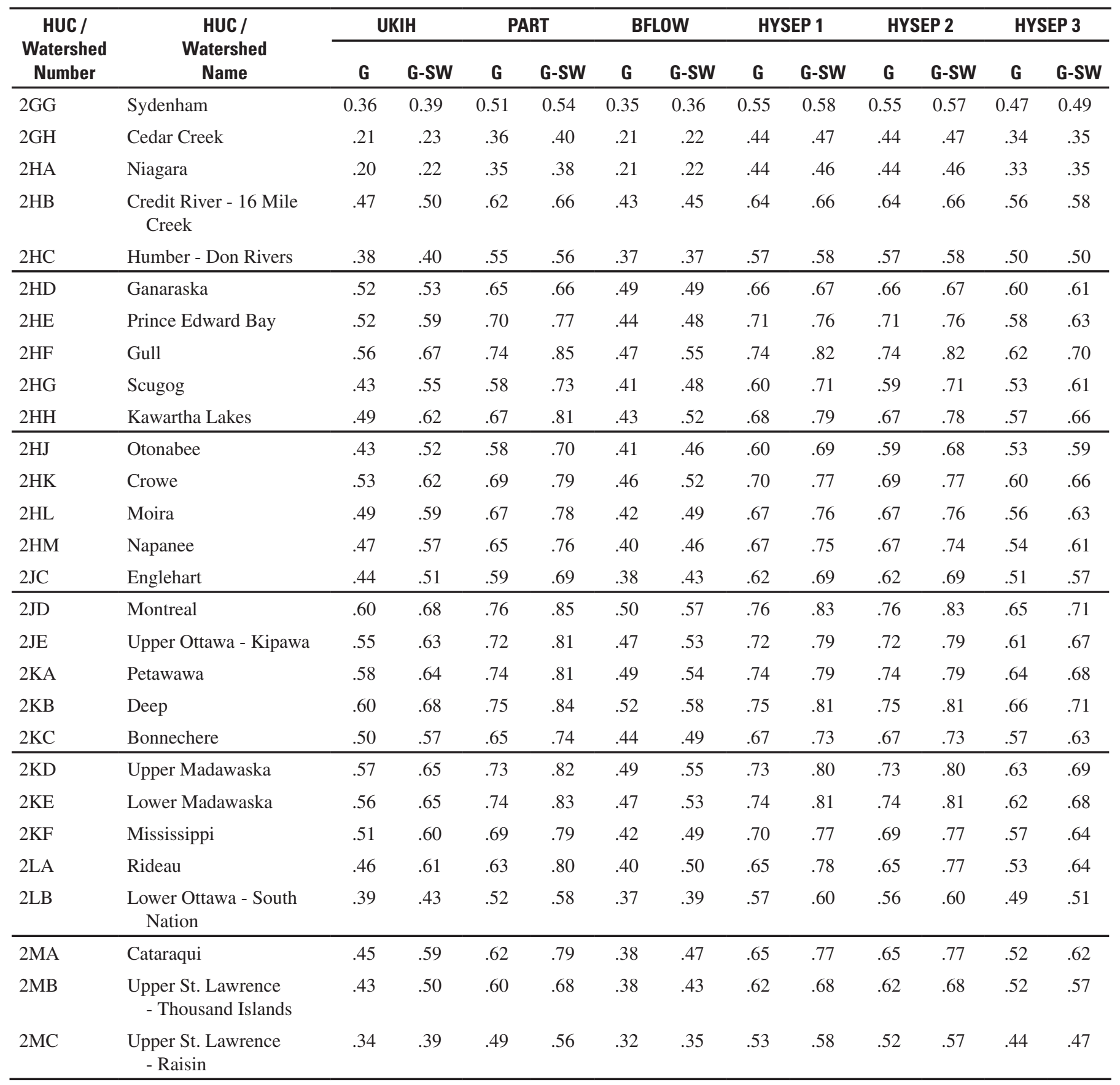




\section{Literature Cited}

Armentrout, G.W., and Wilson, J.F., 1987, Assessment of low flows in streams in northeastern Wyoming: U.S. Geological Survey Water-Resources Investigations Report 85-4246, 30 p.

Arnold, J.G. and Allen, P.M., 1999, Validation of Automated Methods for Estimating Baseflow and Groundwater Recharge from Stream Flow Records: Journal of American Water Resources Association v. 35, no. 2, p. 411-424.

Berger, K.P., and Entekhabi, D., 2001, Basin hydrologic response relations to distributed physiographic descriptors and climate: Journal of Hydrology, v. 247, p. 169-182.

Bingham, R.H., 1986, Regionalization of winter low-flow characteristics of Tennessee streams: U.S. Geological Survey Water-Resources Investigations Report 86-4007, 88 p.

Bullock, A., 1988, Dambos and discharge in central Zimbabwe: Unpublished PhD Thesis, University of Southampton, Southampton, U.K.

Burn, D.H., and Boorman, D.B., 1993, Estimation of hydrological parameters at ungauged catchments: Journal of Hydrology, v. 143, p. 429-454.

Cervione, M.A., Richardson, A.R., and Weiss, L.A., 1993, Low-flow characteristics of selected streams in Rhode Island: U.S. Geological Survey Water-Resources Investigations Report 93-4046, 16 p.

Coordinating Committee on Great Lakes Basic Hydraulic and Hydrologic Data, 1977, Coordinated Great Lakes physical data: Detroit, Mich., and Burlington, Ont., 12 p.

Dorr, J.A., and Eschman, D.F., 1970, Geology of Michigan: The Universtiy of Michigan Press, Ann Arbor, 488 p.

Eichenlaub, V.L., 1979, Weather and climate of the Great Lakes region: Notre Dame, Ind., University of Notre Dame Press, 335 p.

Environment Canada, 2002, HYDAT CD Version 2.01: Ottawa, Ontario.

Flynn, R.H., 2003, Development of regression equations to estimate flow durations and low-flow-frequency statistics in New Hampshire streams: U.S. Geological Survey Water Resources Investigations Report WRIR 02-4298, 66 p.

Garcia-Martino, A.R., Scatena, F.N., Warner, G.S., and Civco D.L., 1996, Statistical low-flow estimation using GIS analysis in humid montane regions in Puerto Rico: Water Resources Bulletin, v. 32, no. 6, p. 1259-1271.
Gebert, W.A., and Krug,W.R., 1996, Streamflow trends in Wisconsin's driftless area: Water Resources Bulletin, V.32, no. 4 , p. 733-744.

Government of Canada and U.S. Environmental Protection Agency, 1995, The Great Lakes-An environmental atlas and resource book (3rd ed.): Toronto, Ont., and Chicago, Ill., 46 p.

Great Lakes Commission, 2003, Toward a water resources management decision support system for the Great Lakes - St. Lawrence River Basin: Great Lakes Commission for the Great Lakes States and Provinces, 142 p.

Great Lakes Regional Assessment Group, 2000, Preparing for a changing climate; The potential consequences of climate variability and change-Great Lakes overview (edited by P.J. Sousounis and J.M. Bisanz): Ann Arbor, Mich., University of Michigan, $106 \mathrm{p}$.

Gustard, A., Roald, L.A., Demuth, S., Lumadjeng, H.S. and Gross, R., 1989, Flow Regimes from Experimental and Network Data (FREND), Volume 1 Hydrological Studies: Institute of Hydrology, Wallingford, U.K., 344 p.

Holtschlag, D.J., and Nicholas, J.R., 1998, Indirect groundwater discharge to the Great Lakes: U.S. Geological Survey Open-File Report 98-579, 25 p.

Lacey, G.C., and Grayson, R.B., 1998, Relating baseflow to catchment properties in south-eastern Australia: Journal of Hydrology, v. 204, p. 231-250.

Manninen, C., and Gauthier, R., 1999, Living with the lakesUnderstanding and adapting to Great Lakes water level changes: Ann Arbor, Mich., and Detroit, Mich., Great Lakes Commission and U.S. Army Corps of Engineers, 39 p.

Mazvimavi, D., 2003, Estimation of flow characteristics of ungauged basins: Case study in Zimbabwe: $\mathrm{PhD}$ Thesis, Wageningen University and International Institute for GeoInformation Science and Earth Observation.

Mazvimavi, D., Meijerink, A.M.J., and Stein, A., 2004, Prediction of base flows from basin characteristics: a case study from Zimbabwe: Hydrological Sciences, v. 49, no. 4, p. 703-715.

Nathan, R.J., and McMahon, T.A., 1990, Identification of homogenous regions for base flow and recession analyses: Journal of Hydrology, v. 121, p. 217-238.

Nathan, R.J., and McMahon, T.A., 1992, Estimating low flow characteristics in ungauged catchments: Water Resources Management, v. 6, p. 85-100.

Ontario Geological Survey, 2000, Quaternary geology, seamless coverage of the province of Ontario: Ontario Geological Survey, ERLIS Data Set 14. 
Piggott, A.R., Brown, D., and Moin, S, 2002, Calculating a groundwater legend for existing geological mapping data, p. 863-871, in D. Stolle, A.R. Piggott and J.J. Crowder (ed.) Ground and Water: Theory to Practice, Proceedings of the 55th Canadian Geotechnical and 3rd Joint IAH-CNC and CGS Groundwater Specialty Conferences, 20-23 October, 2002, Southern Ontario Section of the Canadian Geotechnical Society, Niagara Falls, Ontario.

Piggott, A.R., Brown, D., Moin, S., and Mills, B., 2001.

Exploring the dynamics of groundwater and climate interaction: p. 401-408. In M. Mahmoud, R. van Everdingen and J. Carss (ed.), Proceedings of the 54th Canadian Geotechnical Conference and 2nd Joint IAH-CNC and CGS Groundwater Specialty Conference, Calgary, Alberta, Canada.

Piggott, A.R., Moin, S., and Southam, C., 2005, A revised approach to the UKIH method for the calculation of base flow: National Water Research Institute Contribution.

Ries III, K.G., 1994, Development and application of generalized-least-squares regression models to estimate low-flow: U.S. Geological Survey Water-Resources Investigations Report 94-4155, 33 p.

Rutledge, A.T., 1998, Computer programs for describing the recession of ground-water discharge and for estimating mean ground-water recharge and discharge form streamflow data - update: U.S. Geological Survey Water-Resources Investigations Report 98-4148, 43 p.

Sefton, C.E.M., and Howarth, S.M., 1998, Relationship between dynamic response characteristics and physical descriptors of catchments in England and Wales: Journal of Hydrology, v, 211, p. 1-16.

Sloto, R.A., and Crouse, M.Y., 1996, HYSEP: A computer program for streamflow hydrograph separation and analysis: U.S. Geological Survey Water-Resources Investigations Report 96-4040, 46 p.

Smakhtin, V.Y., 2001, Low flow hydrology: a review: Journal of Hydrology, 240: 147-186.

Soller, David R., 1998, Map showing the thickness and character of Quaternary sediments in the glaciated United States east of the Rocky Mountains: U.S. Geological Survey Miscellaneous Investigations Series Map I-1970, scale $1: 1,000,000$.

Tague, C., and Grant, G. E., 2004, A geological framework for interpreting the low-flow regimes of Cascade streams, Willamette River Basin, Oregon: Water Resources Research, 40, W04303, doi:10.1029/2003WR002629.

Vogel, R.M., and Kroll, C.N., 1992, Regional geohydrologicgeomorphic relationships for the estimation of low-flow statistics: Water Resources Research, v. 28, no. 9, p. 24512458.
Winter, T.C., 2001, The concept of hydrologic landscapes: Journal of American Water Resource Association, v. 37, p. 335-350.

Yokoo, Y., Kazama, S., Sawamoto and Nishimura, H., 2001, Regionalisation of lumped water balance model parameters based on multiple regression: Journal of Hydrology, v. 246, p. 209-222.

\section{Appendix A: Hydrologic Data (4 CD-ROMs, inside back cover)}




$\frac{1}{50}$

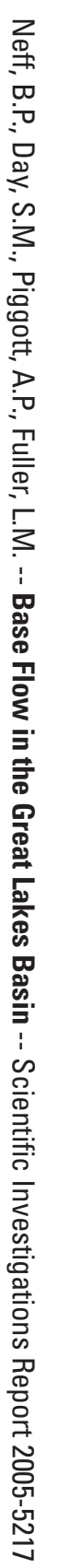

